IZA DP No. 9201

Do Anti-Bullying Laws Reduce Youth Violence?

Joseph J. Sabia

Brittany Bass

July 2015 


\title{
Do Anti-Bullying Laws Reduce Youth Violence?
}

\author{
Joseph J. Sabia \\ San Diego State University \\ and IZA \\ Brittany Bass \\ University of California, Irvine
}

Discussion Paper No. 9201

July 2015

IZA
P.O. Box 7240
53072 Bonn
Germany

\author{
Phone: +49-228-3894-0 \\ Fax: +49-228-3894-180 \\ E-mail: iza@iza.org
}

\begin{abstract}
Any opinions expressed here are those of the author(s) and not those of IZA. Research published in this series may include views on policy, but the institute itself takes no institutional policy positions. The IZA research network is committed to the IZA Guiding Principles of Research Integrity.

The Institute for the Study of Labor (IZA) in Bonn is a local and virtual international research center and a place of communication between science, politics and business. IZA is an independent nonprofit organization supported by Deutsche Post Foundation. The center is associated with the University of Bonn and offers a stimulating research environment through its international network, workshops and conferences, data service, project support, research visits and doctoral program. IZA engages in (i) original and internationally competitive research in all fields of labor economics, (ii) development of policy concepts, and (iii) dissemination of research results and concepts to the interested public.
\end{abstract}

IZA Discussion Papers often represent preliminary work and are circulated to encourage discussion. Citation of such a paper should account for its provisional character. A revised version may be available directly from the author. 


\section{ABSTRACT}

\section{Do Anti-Bullying Laws Reduce Youth Violence?*}

This study is the first to comprehensively examine the effect of state anti-bullying laws (ABLs) on youth violence. Using data from a variety of sources - including the Youth Risk Behavior Surveys, Uniform Crime Reports, and newly collected data on school shootings - we find that the enforcement of strict, comprehensive school district anti-bullying policies is associated with a 7 to 13 percent reduction in school violence and an 8 to 12 percent reduction in bullying. Our results also show that anti-bullying policy mandates are associated with a reduction in minor teen school shooting deaths and violent crime arrests. A causal interpretation of our results is supported by falsification tests on older young adults for whom ABLs do not bind.

JEL Classification: $\quad 128$

Keywords: bullying, youth violence, anti-bullying laws, school shootings

Corresponding author:

Joseph J. Sabia

Department of Economics

San Diego State University

5500 Campanile Drive

San Diego, CA 92182-4485

USA

E-mail: jsabia@mail.sdsu.edu

\footnotetext{
* The authors thank Sara Markowitz, Mark Duggan, and Rosa Minhyo Cho for useful comments and suggestions on this paper. We thank Thanh Tam Nguyen for excellent research assistance. Special thanks are owed to D. Mark Anderson, who graciously made school shooting data available to these authors. We also thank conference participants at the Southern Economic Association (SEA) and the Association of Public Policy Analysis and Management (APPAM) as well as seminar participants at San Diego State University for useful comments and suggestions on an earlier draft of this paper. The authors declare that we have no relevant or material financial interests that relate to the research described in this paper.
} 


\section{Introduction}

"[Following] the Columbine High School massacre, school shootings have gone from a rare, shocking aberration to a frequent, yet still shocking, tragedy. [And] even if they're not getting beat up or shot at, students routinely endure verbal assaults and torment from other students-often as school faculty look the other way, or worse, join in. For many children and teens across the country, school feels like a hostile, oppressive, and dangerous place." (Klein, The Bully Society 2012)

Bullying is defined by the U.S. Department of Health and Human Services as "unwanted, aggressive behavior among school-aged children that involves a real or perceived power imbalance, and the behavior is repeated or has the potential to be repeated" (U.S. Department of Health and Human Services 2014a). It can take the form of verbal abuse or physical violenceincluding behavior that crosses criminal thresholds - and may be transitory or permanent in nature (American Psychological Association 2014). In 2011, nearly seven million youths—or 28 percent of those ages 12 to 18-were bullied in the United States (NCES 2012). While bullying has been identified across all demographic groups, historically marginalized individuals, such as lesbian, gay, bisexual, and transgendered (LGBT) youths (Friedman et al. 2006; Daley et al. 2008; Kosciw et al. 2009), youths with disabilities (Blake et al., 2014; Turner et al. 2011; Cappadocia et al. 2012), females (Faris and Felmlee 2011; Kumpulainen et al. 1999; Craig 1998), and racial minorities (Langdon and Preble 2007; Fox and Stallworth 2005; Carlyle and Steinman 2007) have been found to be disproportionately affected.

Bullying victimization has been linked to a variety of adverse health and human capital outcomes, including poor mental health (Hansen and Lang, 2014; Juvonen et al. 2010; Duncan 1999; Seals and Young 2003; Bond et al. 2001), diminished student engagement (Nansel et al. 2001), poor academic performance (Eriksen et al. 2014; Konishi et al. 2010), and less social connectedness (Nansel et al. 2001; Nansel et al. 2004). In addition, repeated incidents of bullying have been found to be associated with attempted or completed suicides (Kaltiala-Heino et al. 2010; Carney 2000) and even an increased risk of school shootings by those victimized (Klein 2012).

In response to increased public awareness of bullying — and its potentially adverse health and human capital consequences-all 50 states and the District of Columbia have enacted antibullying laws (ABLs) that impose mandates on school districts to adopt anti-bullying policies. 
There is substantial heterogeneity across states in the comprehensiveness and strictness of these mandates. Some ABLs provide non-binding recommendations for school bullying policies, while others include comprehensive provisions requiring school districts to (i) keep written records of students' reporting of bullying to school officials, as well as each incident's resolution (ii) adopt a graduated range of sanctions for acts of bullying, and (iii) provide training for all school staff on preventing, identifying, and responding to bullying. Other ABLs require schools to report incident-by-incident school responses to bullying to both the state Department of Education and parents.

There are a number of channels through which ABLs could reduce student violence. In a rational crime (or "rational bullying") framework (Becker 1968), potential bullies weigh the expected costs and benefits of bullying. ABLs may raise the expected costs of bulling by increasing the probability of punishment via increased school monitoring and by reducing victims' reporting costs. ABLs may also increase the severity of punishments through graduated sanctions for bullying. In addition, the educational components of ABLs may change students' tastes for bullying, reducing potential bullies' expected benefits. Finally, provisions of ABLs that require schools to make bullying policies - and school responses to violations of those policies-publicly available may incentivize reputation-minded schools to more efficiently allocate resources to deter bullying.

On the other hand, there may be unintended consequences of anti-bullying legislation. By mandating that schools devote additional resources to combat bullying, often without additional state dollars, ABLs may require schools to change their mix of inputs to produce education, which could result in substitution away from other inputs (e.g. extracurricular activities, athletics, and teacher quality) that have the unintended consequence of diminishing students' social connectedness or even reducing potential bullies' opportunity costs of time. Additionally, because ABLs only raise the costs of bullying on school property, these laws may simply shift bullying off of school property rather than reduce the overall prevalence of bullying. Finally, the provision of public information on school bullying policies may increase the likelihood that potential bullies are able to avoid detection.

Using data from a variety of data sources_-including the Youth Risk Behavior Surveys, the Uniform Crime Reports, and newly collected school shooting data-this study presents the first comprehensive examination of the effect of state ABLs on school safety, bullying, and 
youth violence. We find that the strict enforcement of school district policy mandates rated as "high intensity" by the Department of Education is associated with a 7 to 13 percent reduction in high school violence and an 8 to 12 percent reduction in bullying. Moreover, we find that the enforcement of comprehensive state ABLs is associated with a reduction in teen school shootings and violent crime, suggesting potentially important social benefits of anti-bullying policies. A causal interpretation of our results is supported by their robustness to the inclusion of controls for state-specific time trends and policy leads, as well as falsification tests on older young adults for whom ABLs do not bind.

\section{Background}

According to a 2013 national survey, 92 percent of parents with minor children believe that bullying contributes to violence in the United States (Peters 2013). Moreover, 78 percent of adults believe that bullying prevention programs should be part of school curricula (Bushaw et al. 2012). Reflecting this concern, public health and education agencies have taken a more high profile role to combat bullying. In 2011, the Department of Health and Human Services (DHHS), in conjunction with the Department of Education's Federal Partners in Bullying Prevention Steering Committee (FPBPSC), launched Stopbullying.gov to provide information to parents, school officials, and students on how to identify, prevent, and respond to bullying (U.S. Department of Health and Human Services 2014b).

A number of private not-for-profit firms have also taken action to deter school bullying. For example, the Parent Advocacy Coalition for Educational Rights' (PACER) National Bullying Prevention Center was founded in 2006 to:

"...actively lead social change, so that bullying is no longer considered an accepted childhood rite of passage. PACER provides innovative resources for students, parents, educators, and others, and recognizes bullying as a serious community issue that impacts education, physical and emotional health, and the safety and well-being of students." (PACER, 2014) ${ }^{1}$

A wide body of scholarship in the sociology and psychology literatures has found that bullying is associated with a myriad of adverse health and human capital outcomes (Rothon et al.

\footnotetext{
${ }^{1}$ To take another example, Bully Police USA, a high-profile private watchdog group, advocates for the adoption of strict state and local anti-bullying legislation.
} 
2011; Wolke et al. 2013; Wilkins-Shurmer et al. 2003; Hepburn et al. 2012; Bond et al. 2001; Glew et al. 2005; Kim et al. 2005; Gini and Pozzoli 2009). Victims of bullying have been found to be more emotionally distressed (Gladstone et al. 2006; O'Brennan et al. 2009; Duncan 1999; Nansel et al. 2001), less socially connected (O'Brennan et al. 2009; Eisenberg et al. 2003; Juvonen et al. 2003), and less academically prepared (Eisenberg et al. 2003; Strøm et al. 2013; Juvonen et al. 2010) than their non-bullied counterparts. Interestingly, perpetrators of bullying have been found to be in worse mental health (Undheim et al. 2010; Ng et al. 2008; Seals and Young 2003; Kaltiala-Heino et al. 1999), more likely to abuse alcohol and drugs (Kaltiala-Heino et al. 2000), and more likely to carry weapons (Nansel et al. 2004) than those who do not bully (Saluja et al. 2004; Arseneault et al. 2006; Bender and Losel 2011). Bullying has also been linked to school shootings, either by bullies carrying out acts of violence against their perpetrators or victims of bullying seeking revenge on their tormenters (see, for example, Klein 2012). ${ }^{2}$

An important limitation of this literature, however, is that bullying victimization (and perpetration) is treated as exogenous to student well-being. This assumption may be problematic if difficult-to-measure characteristics of bullies and their targets—-such as discount rates, personality, or family background characteristics — are related to both the probability of bullying victimization and student outcomes. Recent work by Eriksen et al. (2014) attempts to disentangle the human capital effects of bullying from selection and finds evidence of a causal link.

A number of recent studies have examined the relationship between anti-bullying policies - a plausibly exogenous source of variation in bullying — and student well-being. However, these studies have been either case studies of particular school policies (Jeong and Lee 2013; Salmivalli et al. 2011) or focused on one or two states (Green et al. 2014), used either a simple before-after estimator (Fekkes et al. 2006) or cross-sectional variation in policies for identification (Due et al. 2005). The results of these studies have been mixed. A study of Texas schools found higher bullying prevalence in schools with anti-bullying policies as compared to

\footnotetext{
${ }^{2}$ To take three examples from Klein (2012), (i) on February 12, 2007 in E.O. Green Junior High School in Oxnard California, Brandon McInerney (age 14) shot and killed classmate Larry King because King was gay and McInerney was "disgusted" by King's "flamboyant behavior; (ii) on March 21, 2005, Jeff Weise (age 16) shot five students, one adult staff member and committed suicide, in part, "because he was teased because he was heavy and wore 'Goth' clothing; and (iii) on February 2, 1996, Barry Loukatis (age 14) shot and killed two students (including the student who reportedly bullied him) because he was a repeated victim of sexual orientation-based taunting and teasing.
} 
those without such policies (Jeong and Lee 2013); a comparison of high school bullying rates in Delaware and Illinois found lower bullying rates in Delaware, which has a stronger anti-bullying statute (West 2014); and a study of Finnish schools found that students in schools with an antibullying program faced 1.32 to 1.94 times less bullying than students in schools without such programs (Salmivalli et al. 2011).

Our study contributes to the existing literature in several ways. This study is the first to comprehensively examine the effect of state ABLs on school safety, bullying, and youth violence, including school shootings. We undertake a number of empirical strategies to provide support for the common trends assumption of our difference-in-difference models, including falsification tests on older young adults for whom state ABLs should not bind. Second, given considerable differences across states in anti-bullying statutes (U.S. Department of Education 2011), we carefully explore heterogeneity in policy effects by type of ABL. Third, we examine whether the effects of state ABLs extend to behavior that crosses the criminal threshold, including school shootings.

\section{Data and Measures}

YRBS Data. Our initial analysis uses data drawn from repeated cross-sections of both the National and State Youth Risk Behavior Surveys (YRBS) from 1993 to 2013. The National YRBS is conducted biennially by the Centers for Disease Control and Prevention (CDC) and, when weighted, is representative of the population of U.S. high school students. The State YRBS surveys are also administered to high school students and contain most of the questions in the National YRBS (NYRBS). While the state surveys are coordinated by the CDC, they are usually conducted by state education and health agencies. ${ }^{3}$ The augmentation of National with State YRBS data has been employed in a number of recent studies examining the effects of a number of state-level public policies_cigarette taxes (Hansen et al. 2015), medical marijuana laws (Anderson et al. 2014), parental involvement laws for abortion (Sabia and Anderson 2014), and minimum wages (Sabia et al. 2014)—on risky behaviors. The YRBS is well suited for this study because it contains data on several measures of school safety, violent behavior, and bullying.

\footnotetext{
${ }^{3}$ Estimates from the state YRBS are designed to be representative at the state level, but recent research with these data has utilized Census population estimates to introduce weights that will make these data representative at the national level as well (Anderson and Elsea forthcoming, Anderson et al. forthcoming, Sabia et al. 2014).
} 
Using the YRBS data, we identify four key measures of school safety. First, we measure whether the respondent avoided school because of concerns about safety issues using answers to the following questionnaire item:

"During the past 30 days, on how many days did you not go to school because you felt you would be unsafe at school or on your way to or from school?"

We generate a dichotomous variable, Unsafe, set equal to 1 if the student reported a positive number of days not attending school and equal to 0 otherwise. In the YRBS, 6.3 percent of respondents in our sample reported not attending school at least one day in the last 30 days because they felt unsafe (see Table 1). In addition to the above coding, we also experiment with creating a continuous measure of this outcome.

Next, respondents were asked whether they had been in a physical altercation on school property during the previous year:

"During the past 12 months, how many times were you in a physical fight on school property?"

Fight in School is coded equal to 1 if the student reported being in a physical fight on school property at least once during the past 12 months, and 0 otherwise. We find that 12.2 percent of respondents reported having been in a physical fight on school property. Note that the because this survey item asks respondents about safety in the prior year rather than the prior 30 days, we experiment with lagging our ABL policy variable to better align the timing of the safety outcome with the effective date of the policy.

As noted above, ABLs could incentivize bullies to change the location of bullying rather than reduce total bullying. Therefore, we also generate a dichotomous variable, All Fight, set equal to 1 if the student reported being in any physical fights during the past 12 months and 0 otherwise. ${ }^{4}$ In our sample, 31.2 percent of students reported any fighting.

Finally, students were asked about weapons-related threats in school. Specifically, respondents were asked:

"During the past 12 months, how many times has someone threatened or injured you with a weapon such as a gun, knife, or club on school property?"

\footnotetext{
${ }^{4}$ The questionnaire item in the YRBS about total physical fights was, "During the past 12 months, how many times were you in a physical fight?"
} 
Threat is coded equal to 1 if the student reported being threatened or injured at least once during the past 12 months, and coded as 0 if the student had not been threatened. We find that 8.0 percent of the sample reported being threatened or injured during the past 12 months. Figure 1 shows national trends for each of the above outcomes during the 1993 to 2013 period, reflecting some improvement in perceived school safety during the time states were enacting ABLs.

In addition to the four main measures of school safety defined above, we directly measure bullying — which could include non-physical bullying such as taunting or teasingusing responses to the following YRBS survey item:

\section{"During the past 12 months, have you ever been bullied on school property?"}

We code Bullied equal to 1 if the student responded "yes" and 0 otherwise. The advantage of this measure is that it captures bullying behavior more comprehensively; the chief disadvantage is that it is only available in the final three waves of the YRBS, in 2009, 2011, and 2013. However, as noted below, this is a period during which we observe many state law changes. In our sample, 20.1 percent of the sample reported being the victim of bullying on school property, comparable to recent NCES data reports.

It is important to recognize that each of the above measures of bullying or school safety is self-reported in nature. If ABLs induce more students to be willing to admit (and report) bullying — including on a survey - then estimated effects of ABLs may be biased upward. To supplement our self-reported measures of school safety, we augment our YRBS analysis with objective data on violent behavior in schools.

School Shooting Data. First, we exploit use a unique dataset constructed by Anderson and Sabia (2015) on school shooting deaths. Their primary source for data on school shootings comes from the National School Safety Center's (NSSC) report on School Associated Violent Deaths that covers the period 1992 through 2010. ${ }^{5}$ To supplement the NSSC's report and ensure a comprehensive coverage of school shootings, they used the following additional data sources: Columbine-angels.com (2015), Doll (in press), Everytown.org (2015a), Fleet and Fleet (2010), Klein (2012), Lieberman (2008), National School Safety and Security Services (2010), and

\footnotetext{
${ }^{5}$ The NSSC report can be found at: http://www.schoolsafety.us/media-resources/school-associated-violent-deaths
} 
Stoptheshootings.org (2013). These sources, in addition to our internet searches of newspaper archives, allowed us to extend our coverage from 1993 to 2012.

We generate state-by-year data indicating whether a school shooting occurred in each state-year, the circumstances surrounding the shooting, the age(s) of the shooter(s), and whether the shooting occurred on an elementary, middle school, high school, or college/university campus. We define a teen school shooting death as one that (i) occurred on high school, middle school or elementary campus, (ii) was committed by a shooter ages 13-to-17, and (iii) involved a death.

Teen Shooting Involving Death is coded as 1 if the teen school shooting resulted in a death (homicide, suicide, or both). Teen Shooting Involving Homicide is coded as 1 if the teen school shooting involved a homicide. During the 1993 to 2012 period, we identify 135 school shootings, 73 of which involved a homicide.

Youth Arrest Data. Our second source of "objective" data is drawn from the Federal Bureau of Investigation's Uniform Crime Reports (UCR) from 1993 to 2012 to measure property and violent crime arrests for minor teens. During this period, the average number of property crime arrests for minor teens was 1,999.9 per 100,000 and the average violent crime arrest rate was 325.2 per 100,000 .

Anti-Bullying Laws. We begin by generating a dichotomous measure, $A B L$, which is an indicator for whether the state mandates school district anti-bullying policies. The effective dates for state-mandated school district anti-bullying policies are determined in one of two ways. 32 state ABLs specified, in the text of the law, the date by which school districts were required to begin enforcing anti-bullying policies. We collect this information from the U.S. Department of Education's Office of Planning, Evaluation and Policy Development (U.S. Department of Education 2011, Exhibit 11) and our own investigation of state legislative histories. State ABLs without separate effective dates written into the law are coded as being effective on the legislation's effective date. Table 2 presents the effective dates for each state's anti-bullying school district policy mandate. Every state except Montana enacted an anti-bullying law during the 2001 to 2013 period, with Colorado enforcing the first law in August 2001, and New York and Virginia most recently enforcing a law in July 2013. In April 2015, Montana became the last state to adopt an ABL. 
Given that there was substantial heterogeneity in the type of anti-bullying law adopted by each state, the U.S. Department of Education (DOE) categorizes these laws by their comprehensiveness and strictness. We first use DOE guidelines to measure whether a state ABL was accompanied by a "model policy." A model policy is defined as an anti-bullying policy established by state Departments of Education that provides guidance to districts and schools on how to address bullying. Twenty percent of states that that adopted an ABL also adopted a model policy.

Next, in an effort to categorize the breadth and strictness of state ABLs, the DOE, following a joint DOE and DHHS-hosted Federal Partners in Bullying Prevention Summit, commissioned a legal evaluation of the comprehensiveness, strength of enforcement, and reporting strictness of 16 components of each state law. Specifically, the DOE examined the extent to which each state legislation addressed four specific areas: (i) Definitions of Terms, (ii) District Policy Development and Review, (iii) School District Policy Components (Written Records and Anonymous Student Reporting Policies, Bullying Definitions, Investigation Policies, Consequences/Sanctions Policies, and Post-Bullying Mental Health Services), and (iv) Additional District Policy Components (Parental Communications/Staff Training/Transparency, and Legal Remedies). ${ }^{6}$ Importantly, these DOE evaluations were not based on case studies of policy impacts, but by legal interpretation of the statutes. The DOE assigns a score of 0 to 2 to each component, measuring the overall expansiveness of each provision, and creates an aggregate "intensity rating" based on these scores (see U.S. Department of Education 2011 for a detailed discussion of these ratings).

Components rated a "0" by the DOE were usually those components not present in a state ABL. Components rated as a "2" (most expansive) were more inclusive in nature, more prescriptive, used less discretionary language, and established clearer measures of accountability (see U.S. Department of Education 2011 for the complete list of rating criteria for each component). ${ }^{7}$ For example, a state ABL's Purpose component, which addressed the purpose of

\footnotetext{
${ }^{6}$ These 16 dimensions can be found at: www.stopbullying.gov/laws/key-components/index.html ${ }^{7}$ According to the DOE:
}

"Expansiveness was interpreted differently across components; however, components in law that were rated as more expansive are generally: a) more inclusive (e.g., defined prohibited behavior broadly without any limiting conditions, or extended school jurisdiction to cover off-campus conduct); b) are more prescriptive (e.g., used concrete directives to convey policy expectations); c) use less discretionary 
laws and policies and prohibitions against bullying, was rated as a "0" if the state ABL did not contain a prohibition against bullying; a "1" if the state law explicitly specified a prohibition against bullying, but did not contain language articulating the purpose or intent; and a "2" if the state law explicitly specified both a prohibition against bullying and language articulating the purpose or intent. The score assigned to each component was then summed to generate a composite score ranging from 0 to 32 . Table 2 shows the DOE intensity rating for each state. Washington received the highest score from the DOE with 30 points, and Minnesota and Texas have the lowest scores with 3 and 5 points, respectively.

We categorize laws by the interquartile range of composite intensity scores: High Intensity $A B L$, set equal to 1 if the state has an $\mathrm{ABL}$ with a DOE intensity rating in the upper $25^{\text {th }}$ percentile of ratings (corresponding to composite scores between 21 and 32), and 0 otherwise; Moderate Intensity $A B L$ set equal to 1 if the state has an ABL with a DOE intensity rating composite score in the $25^{\text {th }}$ to $75^{\text {th }}$ percentile of ratings (corresponding to composite scores between 13 and 20) and 0 otherwise; and Low Intensity $A B L$ set equal to 1 if the state has an ABL with a DOE intensity rating composite score in the lower $25^{\text {th }}$ percentile of ratings (corresponding to composite scores between 0 and 12) and 0 otherwise. We experiment with other cutoffs corresponding to quartiles and quintiles of the distribution and find a similar pattern of results to those reported in the main tables. In our sample, 13.9 percent of respondents lived in states enforcing ABLs with intensity ratings in the top $25^{\text {th }}$ percentile.

As noted above, two of the four areas into which the DOE categorizes state ABLs relate specifically to school district policies. We restrict attention to these policy components and examine the effect of district policy-specific intensity ratings on our outcomes. High Intensity District Policy, set equal to 1 if the state has an ABL with a district policy intensity rating in the upper $25^{\text {th }}$ percentile of ratings, and 0 otherwise; Moderate Intensity District Policy set equal to 1 if the state has an ABL with a district policy intensity rating composite score in the $25^{\text {th }}$ to $75^{\text {th }}$ percentile of ratings and 0 otherwise; and Low Intensity District Policy set equal to 1 if the state has an $\mathrm{ABL}$ with a district policy intensity rating composite score in the lower $25^{\text {th }}$ percentile of ratings and 0 otherwise.

language (e.g., used the term "shall” instead of "may"); or d) establish stronger measures of accountability." (DOE 2011) 
Next, among DOE-identified school district policy components, we examine five mandates likely to most affect marginal bullying decisions. The first component, Written Records \& Reporting mandates schools to maintain written records of all incidents of bullying reported to school officials, as well as a procedure that would allow students, staff, or parents to anonymously report suspected bullying. For example, California's educational code requires the state DOE to assess whether local schools have maintained documentation of complaints and their resolution for a minimum of one review cycle. These policies are expected to increase the costs of bullying by increasing the probability of detecting and punishing potential bullies.

Second, an Investigations mandate requires that schools strictly enforce a procedure for promptly investigating and responding to any reported incidents of bullying on school grounds. For instance, Massachusetts's Investigations mandate requires that "[u]pon receipt of such a report, the school principal or a designee shall promptly conduct an investigation" (Mass. Adv. Legis. Serv. Ch. No. 71.37O(g) 2010).

Third, a Consequences provision requires school districts to provide a detailed range of consequences and sanctions for bullying occurrences. For example, under the California ABL, students who engage in an act of bullying may be suspended from school or recommended for expulsion (California Education Code Section 48900-48927). Investigations and Consequences mandates are expected to raise the expected costs of bullying by increasing the probability of detection and punishments if caught.

Fourth, a Training \& Transparency mandate requires (i) communications to students, their families, and school personnel of policies and consequences related to bullying and (ii) training for school staff and faculty on preventing, identifying, and responding to bullying. The Connecticut $\mathrm{ABL}$, for example, requires schools to (i) provide teachers and staff with a bullying prevention and intervention plan, (ii) notify and meet with parents or guardians of the bullies and the victims of verified bullying incidents, and (iii) report all verified incidents to the Department of Education annually (Conn. Rev. Stat. §10-222d 2010).

Finally, a Legal Definitions mandate requires definitions of bullying adopted by school districts conform to those written in the state legislation. For instance, Oregon law requires school district bullying policy to include definitions of "harassment," "intimidation," or "bullying," and "cyberbullying" that are consistent with the state's statues (Or. Rev. Stat. § 
339.356.2 2009). Stricter bullying definitions are likely to result in less ambiguity about whether bullying has occurred and decrease inappropriate bullying behavior

Together, these components are hypothesized to raise the expected costs of bullying behavior to potential bullies by raising the probability of detection (via better detection methods and lowering the costs of reporting to victims) and mandating harsher punishments if detected. In Table 2, we show the states that have strictly enforced each of these components of ABLs.

Using the above five school district policies components, we first estimate the effect of each "high intensity" school district policy mandate (that is receiving a score of "2"), controlling for each of the other components. However, given the high degree of collinearity between school district policy mandates ${ }^{8}$ - and the possibility that interactive effects of these policy mandates are important-we next estimate the effect of states having multiple high intensity district policy components enforced. For instance, five states, including Connecticut, Michigan, New Hampshire, New Jersey, and Vermont, are examples of states strictly enforcing four or more high intensity district policy components. Fourteen states have enforced two or three high intensity district policy components. For instance, Connecticut, Hawaii, Michigan, New Jersey, Vermont, and Washington, have enforced ABLs with the Written Records \& Reporting, Investigations and Consequences mandates. Finally, Arizona, Nevada, and Oregon are examples of strictly enforcing only one component.

\section{Empirical Approach}

We begin by pooling data from repeated cross-sections of the 1993-2013 National and State YRBS and, for our dichotomous outcomes, estimate the following difference-in-difference model via probit:

$$
\mathrm{Y}^{*}{ }_{\mathrm{ist}}=\beta_{0}+\beta_{1} \mathrm{ABL}_{\mathrm{st}}+\boldsymbol{\beta}_{\mathbf{2}}{ }^{\prime} \mathbf{Z}_{\mathrm{it}}+\boldsymbol{\beta}_{\mathbf{3}}{ }^{\prime} \mathbf{E}_{\mathrm{st}}+\boldsymbol{\beta}_{\mathbf{4}}{ }^{\prime} \mathbf{X}_{\mathrm{st}}+\alpha_{\mathrm{s}}+\pi_{\mathrm{t}}+\varepsilon_{\mathrm{ist}}
$$

where $\mathrm{Y}_{\text {ist }}$ is a latent variable measuring safety of student $i$ residing in state $s$ at year $t ; \mathrm{ABL}_{\mathrm{st}}$ is an indicator for whether state mandate for school district anti-bullying policies is in effect in

\footnotetext{
${ }^{8}$ For example, among eight states with high intensity Written Records \& Reporting mandates, half have ABLs with three additional high intensity district policy mandates, three states have two additional high intensity components, and only one has no other high intensity component. We find that approximately half of the identifying variation available in each high intensity component is eliminated by the inclusion of controls for the others.
} 
state $s$ in year $t$ (or a set of indicators indicating the strength of that law, or the components of that law); $\mathbf{Z}_{\text {it }}$ is a vector of demographic controls including gender, age, grade, and race/ethnicity; $\mathbf{E}_{\text {st }}$ is a set of state-specific time-varying education controls, including whether the state is enforcing a zero tolerance school violence policy, child access prevention gun control (CAP) laws, shall issue gun carrying laws, average pupil-teacher ratio, state average teacher salary, National School Lunch Program (NSLP) participation rates, and the share of population with a Bachelor's degree; and $\mathbf{X}_{\mathrm{st}}$ is a vector of state-specific time-varying economic and policy controls, including alcohol policies (beer taxes and zero tolerance drunk driving laws), cigarette taxes, per capita expenditures on police, per capita number of law enforcement employees, child access prevention (CAP) gun laws, concealed carry ("shall issue") laws, the state unemployment rate, and per capita income; $\alpha_{\mathrm{s}}$ is a time-invariant state effect; $\pi_{\mathrm{t}}$ is a state-invariant time effect; and $\varepsilon_{\text {ist }} \sim \mathrm{N}(0,1)$. Our tables below present marginal probabilities estimated at the mean of the right-hand side variables. Continuous outcomes, such as arrest rates are estimated using Ordinary Least Squares (OLS) and include the same set of right-hand-side variables described above.

Identification of $\beta_{1}$ comes from within-state variation in ABLs during the 1993-2013 period. As noted above, 49 states and the District of Columbia enacted bullying laws during the period under study (Table 2). To produce unbiased estimates of $\beta_{1}$, the parallel trends assumption of difference-in-difference models must be satisfied. This may be violated if, for example, (i) states enact ABLs in response to school bullying trends or (ii) if there are timevarying state characteristics not captured in state-specify time-varying education controls or economic and policy controls that are associated with both the adoption of ABLs and with the outcomes under study.

We take a number of tacks to address the possibility of policy endogeneity. First, we add state-specific linear time trends to the right hand-side of equation (1) to control for unmeasured state trends unfolding linearly. Second, to examine whether results are driven by student wellbeing trending differently prior to the implementation of state bullying laws we test the robustness of our estimates to the inclusion of policy leads. Finally, we conduct a set of falsification tests on a set of outcomes similar to those under study for young adults in their 20s, for whom ABLs should not bind, unless there were longer-run consequences of these laws. 
Our key estimation results are shown in Tables 3 through 10. All models present marginal effects from logit or OLS models. For ease of presentation, we focus on estimates of $\beta_{1}$, but estimated coefficients on the controls are available upon request. Standard errors corrected for clustering on the state are in parentheses (Bertrand et al. 2004).

\section{Main Results}

School Safety. In Panel I of Table 3, we present baseline difference-in-difference estimates of the relationship between enforcement of a state ABL and school safety, including only controls for state and year fixed effects. Our estimates show little evidence that state ABLs are associated with economically or statistically significant changes in the probability of not attending school due to an unsafe environment (column 1), physical altercations on or off school property (columns 2 and 3) or weapons-related threats (column 4). Panel II adds controls for individual demographics and economic controls, and Panel III adds controls for education and policy controls. The findings in these panels are qualitatively and quantitatively similar to those presented in Panel I. The precision of our estimates in Panel III is such that we can rule out, with 95 percent confidence, student safety benefits of greater than 2.5 to 9.3 percent. $^{9}$

Could the estimated association we observe in Panels I through III be biased toward zero? This could occur if states that adopt ABLs are experiencing declining trends in student safety and these trends are confounding true beneficial effects of these laws. Moreover, the effects of these laws may be small initially, but could take time to unfold. We explore each possibility in Panel IV of Table 3, where we include three years of policy leads and three years of lagged effects.

Our results provide little support for the hypothesis that student safety was trending differently in the years prior to the adoption of ABLs, both in individual and joint tests of the policy leads. Moreover, we find no evidence that the enforcement of the typical state ABL is associated with significant changes in student safety in the years following the year of enforcement. In Panel V, we test the sensitivity of our estimates to the inclusion of controls for state-specific linear time trends. The results are quantitatively similar.

While the typical state ABL appears to have little or no effect on school safety, we next explore whether there might be heterogeneity in the effect of ABLs by the type of law adopted.

\footnotetext{
${ }^{9}$ The lower bound of the 95 perent confidence interval is calculated as the ratio of the point estimates subtracting the product of 1.96 and the standard error to the mean of the relevant dependent variable.
} 
In Panel I of Table 4, we explore the effect of ABLs with and without a model policy adopted by the state. All models include state linear time trends as controls. We find little evidence that state ABLs either with or without model policies affect school safety.

Next, we explore heterogeneity in the effects of ABLs using overall DOE intensity ratings (Panel II) and DOE intensity ratings specific to school district policy mandates (Panel III). Here, a different pattern of results emerges. We find that the enforcement of high intensity state ABLs- those with composite scores in the top $25^{\text {th }}$ percentile—is associated with a 6.6 to 8.2 percent reduction in the probability of fighting on school property (column 2). The beneficial in-school fighting effect of high intensity state ABLs is larger than for moderate intensity (composite score in middle $50^{\text {th }}$ percentile) or low intensity (composite scores in lower $25^{\text {th }}$ percentile) ABLs (see $\chi^{2}$ tests in the final rows of Panel II). The results also suggest that the effect of high intensity ABLs on overall fighting remains negative (though insignificant), suggesting that high intensity ABLs likely do not simply induce changes in the location of student fighting, but rather reduce net fighting.

In Panel IV, we look inside the "black box" of high intensity school district policy components at five major components. Our results suggest that strictly enforced written records and student reporting requirements are associated with substantial improvements in school safety. We find that the enforcement of ABLs with strict student reporting requirements is associated with a 22.2 percent reduction in the probability of safety-related school absences, a 13.1 percent reduction in the probability of fighting on school property, a 3.8 percent decrease in the probability of overall fighting, and a 25.0 percent decline in the probability of weaponsrelated threats. These results are consistent with the hypothesis that policies that reduce the costs of student reporting and increase expected punishments from bullying and reduce school violence.

While none of the other district policy components is statistically distinguishable from zero at conventional levels, the degree of collinearity between high intensity mandates (see footnote 8) - as well as the possibility that enforcement of multiple high intensity school district policy components may affect school safety-motivates our next set of estimates. In Panel V, we examine interactive effects of our five key school district policy components of ABLs (Written Records \& Reporting, Investigations, Consequences, Training \& Transparency, and Definitions) on school safety. We find that the enforcement of ABLs with multiple high intensity 
school policy components (those with four or more components strictly enforced) is associated with a 13.1 percent reduction in the probability of fighting on school property, a 3.8 percent reduction in the probability of overall fighting, a 15.0 percent reduction in the probability of weapons-related threats, and a (statistically insignificant) 12.7 percent decline in the probability of safety-related school absences. Moreover, it also appears as though the effects of enforcing more components of ABLs are greater than enforcing fewer components. These findings are consistent with the hypothesis that more comprehensive ABLs with strictly enforced policy components that raise the costs of bullying are associated with improvements in school safety. ${ }^{10}$

To ensure that the findings in Table 4 on high intensity ABLs were not driven by differential state trends in school safety in the years prior to the enforcement of these laws, we re-estimate all models in Table 4, but also include policy leads for three years prior to the enforcement of an ABL. The pattern of results in Table 5 suggests that trends prior to the implementation of strictly enforced ABLs cannot explain the school safety effects we estimate in Table $4 .^{11}$

Bullying. If ABLs affect violent behavior in school-a more severe type of bullyingone might also expect "first-stage" effects on broader bullying behavior that includes nonphysical bullying such as taunting or teasing. As noted above, data on self-reported bullying is only available in the final three waves of the YRBS between 2009 and 2013. In Table 6, we examine the impact of state ABLs on the probability of being bullied on school property. Because we have only three data points for each state, we begin with a more parsimonious regression without a wide set of controls. Column (1) includes controls for state and year fixed effects, column (2) adds controls for individual demographics controls and state-specific timevarying economic controls, and column (3) adds state-specific education and policy controls. Given that there are only three years of data available for this outcome, the inclusion of statespecific time trends eliminates much of the identifying variation. An auxiliary regression of state

\footnotetext{
${ }^{10}$ Using a one year lag of ABLs produces a similar pattern of results, available upon request

${ }^{11}$ Estimates using continuous measures of frequency of school absences, physical fights, and weapons-related threats to capture safety measured along the intensive margin, presented in Appendix Table 1, suggest a similar pattern of results.
} 
ABLs on controls shows that the inclusion of state-specific linear time trends increases our estimate of $\mathrm{R}^{2}$ from 80 percent to 94 percent. ${ }^{12}$

Difference-in-difference estimates show that the enforcement of the average state ABL is associated with a 3.5 to 4.5 percent reduction in the probability of being bullied on school property (Panel I). While we find the enforcement of state ABLs without a model policy is associated with a significant reduction in the probability of being bullied, this estimate is generally not statistically different from the effect of state ABLs with a model policy (Panel II). Importantly, the enforcement of high intensity state ABLs appears to be effective at reducing bullying. We find that the enforcement of high intensity state ABLs is associated with an 8.5 to 9.5 percent reduction in the probability of being bullied (Panel III), an effect that appears to be driven by moderate intensity policies (Panel IV).

When examining individual district policy components, we find that the enforcement of Investigations and Consequences components are particularly important. Our results show that these mandates are associated with a 9.5 to 12.4 percent reduction in the probability of being bullied (Panel V). These results are consistent with the hypothesis that school district policies that increase expected punishments from bullying decrease its likelihood. Thus, it appears that strict mandates for written records of students' bullying reports are most important for deterring more severe types of bullying, while investigations and consequences are more important for deterring other forms of bullying. ${ }^{13}$

One concern about our estimates is that they could be contaminated by sample selection bias because the YRBS is a school-based survey. In Table 7, we descriptively explore whether ABLs affect the probability of remaining in high school. Using data from the Current Population Survey, we estimate the effect of ABLs on the probability of not attending high school for those ages 16-to-18. ${ }^{14}$ The results suggest little evidence that ABLs affect high school attendance. Note, however, that these results do not rule out potentially important school enrollment responses. For instance, students who are victimized by bullying may change schools, an outcome masked by our high school attendance measure. Moreover, as Eriken et al. (2014) show,

\footnotetext{
${ }^{12}$ The final column of Appendix Table 2 shows estimates with controls for state-specific linear time trends.

${ }^{13}$ We explore whether there were heterogeneous effects of ABLs by gender and race, but find little evidence of differential effects. These estimates are available upon request.

${ }^{14}$ We include month fixed effects to control for differences in reporting enrollment during summer and school holiday-related vacations.
} 
there may be important educational benefits of alleviating bullying among students who remain in school.

A second concern is that because our measures of bullying and student safety are selfreported, they may be biased because ABLs induce greater reporting of bullying. This may result in our understating the negative effects of ABLs on school violence. To supplement our survey data analysis, we next move to objective measures of violence.

Minor Teen School Shootings and Crime. ABLs could affect criminal behavior via both direct and indirect channels. First, some types of bullying behavior-physical violence, threats, and theft—cross the criminal threshold and ABLs may directly affect them. Second, if noncriminal bullying is a "gateway" to more severe criminal behavior, ABLs may indirectly affect crime. Third, those who are victims of bullying sometimes seek out revenge against those they perceive as tormenting them (Klein 2012).

In the first two columns of Table 8, we estimate the effect of ABLs on the probability of a minor teen school shooting death. ${ }^{15}$ Column (1) presents results for any school shooting death and column (2) restricts the school shooting to involve a homicide. Our results show that the enforcement of state ABLs with a relatively higher DOE intensity rating, is associated with a reduction in the probability of a teen school shooting. This result, consistent with survey data findings above, suggests that ABLs generate important social benefits.

In the remaining two columns of Table 8, we present findings on criminal arrest rates of those ages 13-to-17 using the Uniform Crime Data. The dependent variable is measured as the natural $\log$ of the minor crime arrest rate. We find evidence that state ABLs with model policies, high-intensity district policy components, and four or more high intensity district policy components are associated with substantial declines in minor property and violent crime arrest rates. Together, the findings in Table 8 suggest that the social benefits of ABLs may extend to amelioration of violent behavior.

\section{Falsification Tests}

Despite controls for state-specific time trends and policy leads, one could still be concerned that the prior estimates could be contaminated by a violation of the parallel trends

\footnotetext{
${ }^{15}$ These models are estimated via linear probability model.
} 
assumption. Thus, in Table 9 we conduct a set of falsification tests on populations and outcomes that should be unaffected by state ABLs. First, in columns (1) and (2), we estimate the effect of state ABLs on school shootings committed on college or university campuses by those under age 30. Our estimates provide little evidence that the enforcement of ABLs is associated with changes in the probability of young adult college shootings.

In columns (3) and (4), we show estimates of the effect of ABLs on the natural log of crime arrests rates of 20-to-24 year-olds. Our findings show that ABLs are associated with relatively small and statistically insignificant changes in young adult property or violent arrests. In columns (5) and (6), we draw data from the General Social Survey from 1993 to 2010 to construct two measures of safety-related outcomes for those ages 20-to-24 using responses to the following questionnaire items:

"Is there any area right around here - that is, within a mile - where you would be afraid to walk alone at night?"

"Do you happen to have any shotguns in your home or garage?"

The findings in columns (5) and (6) little evidence that high intensity school district policies (Panel III) or enforcement of multiple high intensity components (Panel VI) are associated with changes in young adult neighborhood safety or shotgun ownership. ${ }^{16}$

Finally, in column (7), we return to high school students in the YRBS and examine the effect of state ABLs on a safety related outcome that should be unaffected by bullying policies: helmet use while riding a bicycle. ${ }^{17}$ The results in column (7) provide little evidence that the enforcement of ABLs is associated with changes in the probability of a teen wearing a helmet.

Difference-in-Difference-in-Difference Estimates. Finally, in Table 10, we estimate triple-difference estimates of the effect of state ABLs on school shootings (columns 1 and 2) and arrest rates (columns 3 and 4 ) of minor teens relative to young adults. Our findings continue to point to evidence that state ABLs are associated with a reduction in teen school shootings and minor teen arrest rates, on the order of 9.3 to 10.8 percent, relative to older young adults in their

\footnotetext{
${ }^{16}$ The results for crime and safety persist when we expand the age group examined for the falsification tests to those ages 19-to-29, matching the school shooting age group.

${ }^{17}$ Not Use Helmet is coded as equal to 1 if the respondent reports not wearing a seatbelt always or almost always and 0 otherwise. While we also considered using seatbelt use while driving as an additional falsification check, this question was only asked in a handful of states in the State YRBS ( 2 to 7 states per year) between 1997 and 2013, except for 2001 and 2003 when this question was included in the National YRBS.
} 
20s. In unreported results, available upon request, we find that these findings persist even after controlling for fully interacted state and year dummies, which control in the most flexible way for unmeasured state-specific time shocks that commonly affect minor teens and young adults in their 20s.

\section{Conclusions}

This study presents the first comprehensive examination of the relationship between state ABLs and school safety, bullying, and youth violence. Difference-in-difference estimates suggest that the enforcement of the typical ABL is associated with small and statistically insignificant changes in student safety in school. However, when we explore heterogeneity in anti-bullying statutes, we find that more strictly enforced comprehensive ABLs are associated with significant improvements in student safety. Specifically, we find that the comprehensive and strict enforcement of ABLs is associated with a 7 to 13 percent reduction in school violence and an 8 to 12 percent reduction in bullying. We also find that comprehensive and strict enforcement of ABLs are associated with a reduction in teen school shootings and a 9 to 11 percent reduction in violent crime arrests of minor teens.

Despite the fact that ABLs appear to generate social benefits, a question remains: are they cost-effective? Restricting our attention to the criminal benefits of ABLs, the estimates presented in this study suggest an average reduction in property and crime offenses of approximately 1,100 . While there is substantial heterogeneity in per-victimization costs of crime, back-of-the-envelope calculations from Miller, Cohen, and Wisersema (1996) suggest a per-offense cost of approximately $\$ 20,000$ (in 2014 dollars). This implies crime-reducing benefits of ABLs $\$ 22$ million for the average state. However, if ABLs alter the career paths of some juvenile criminals, the criminal cost savings could be much larger. For instance, Cohen (2000) estimates an external cost per criminal career of $\$ 1.3$ to $\$ 1.5$ million.

What about the costs of implementing a high intensity state ABL? Minnesota, which implemented a low intensity ABL in 2007, recently considered amending their law to include (unfunded) mandates for comprehensive school staff training and strict reporting requirements. The Minnesota Management and Budget Office estimated this high intensity legislation as costing local school districts approximately \$20 million per year (Minnesota Management and Budget 2013). While this cost estimate represents only one state's ABL — and costs could vary 
widely across states - it does suggest that the social benefits will have to be quite large for a high intensity $\mathrm{ABL}$ to be cost effective.

There are a number of limitations of this study worthy of note. Although our study contributes to estimating the effect of ABLs on school safety, public safety, and student wellbeing, our analysis could benefit from more comprehensive measures of bullying. Because ABLs are intended to deter aggressive bullying behavior and harassment on school property, questions regarding bully victimization and physical or verbal harassment would be useful. Additionally, numerous psychology and sociology studies on bullying and victimization suggest that victims of bullying and bullies themselves exhibit adverse health and psychological effects later in life. Utilizing data over longer time periods would be useful in order to explore whether anti-bullying policies alter individuals' life trajectories. In addition, future work using better data to identify lesbian/gay/bisexual/transgendered (LGBT) and disabled youth will be important to explore whether the benefits of ABLs extend to these groups. 


\section{References}

American Psychological Association. 2014. Bullying. Retrieved on 11 Aug. 2014.

Anderson, D. Mark and David Elsea. 2015. "The Meth Project and Teen Meth Use: New Estimates from the National and State Youth Risk Behavior Surveys." Forthcoming at Health Economics.

Anderson, D. Mark, Benjamin Hansen, and Daniel I. Rees. 2015. "Medical Marijuana Laws and Teen Marijuana Use." Forthcoming at American Law and Economics Review.

Anderson, D. Mark, Benjamin Hansen, and Daniel I. Rees. 2013. "Medical marijuana laws, traffic fatalities, and alcohol consumption. Journal of Law and Economics, 56(2), 333-369.

Anderson, D. Mark and Joseph J. Sabia. 2015. "Child Access Prevention Laws, Youth Gun Carrying, and School Shootings.” Working Paper, San Diego State University.

Argys, Laura, Melinda Pitts, and Astha Sen. 2014. "The Impact of the Business Cycle on Teen Risky Behaviors," Working Paper, Atlanta Federal Reserve Bank.

Arseneault, Louise, Walsh, E, and Trzesniewski, K. 2006. "Bullying victimization uniquely contributes to adjustment problems in young children: a nationally representative cohort study." Pediatrics 118.1: 130-138.

Becker, Gary. 1968. "Crime and Punishment: An Economic Approach". The Journal of Political Economy 76: 169-217.

Bender, Doris, and Friedrich Lösel. 2011."Bullying at school as a predictor of delinquency, violence and other anti-social behaviour in adulthood." Criminal Behaviour and Mental Health 21.2: 99-106.

Bertrand, Marianne \& Duflo, Esther \& Mullainathan, Sendhil. 2004. "How Much Should We Trust Difference and Difference Estimates," Quarterly Journal of Economics, 119(1): 249-275.

Blake, Jamilia J., Kim, ES, Lund, EM, and Zhou, Q. 2014. "Predictors of Bully Victimization in Students With Disabilities A Longitudinal Examination Using a National Data Set." Journal of Disability Policy Studies, DOI: 0.1177/1044207314539012.

Bond, Lyndal, Carlin, J.B., Thomas, L., Rubink, K., and Patton, G. 2001. "Does bullying cause emotional problems? A prospective study of young teenagers." British Medical Journal 323.7311: 480-484.

Bushaw, William, and Shane Lopez. 2012. "Public Education in the United States: A Nation Divided." 2012 Gallop Poll Full Report. Retrieved on 11 Aug. 2014.

Cappadocia, M. Catherine, Jonathan A. Weiss, and Debra Pepler. 2012. "Bullying experiences among children and youth with autism spectrum disorders." Journal of autism and developmental disorders 42.2: 266-277.

California Education Code. 2003. Section 48900-48927. Suspension or Expulsion. Available at: http://www.leginfo.ca.gov/cgibin/displaycode? section=edc\&group $=48001-49000 \&$ file $=48900-48927$

Carlyle, Kellie E., and Kenneth J. Steinman. 2007. "Demographic Differences in the Prevalence, Co-Occurrence, and Correlates of Adolescent Bullying at School." Journal of School Health 77.9: 623-629.

Carney, Jolynn V. 2000. "Bullied to Death Perceptions of Peer Abuse and Suicidal Behaviour during Adolescence." School Psychology International 21.2: 213-223. 
Cohen, Mark A. 2000. "Measuring the costs and benefits of crime and justice", in volume 4: Measurement and Analysis of Crime and Justice 4: 263-316. Criminal Justice 2000. Available at: https://www.ncjrs.gov/criminal_justice2000/vol_4/04f.pdf

Columbine-angels.com. 2015. "School Violence Around the World." Available at: http://www.columbine-angels.com/School_Violence.htm.

Connecticut General Statutes. 2011. Section 10-222d. Policy on bullying behavior. Available at: http://www.cga.ct.gov/coc/PDFs/bullying/bullying_statutes_11-10.pdf

Craig, Wendy M. 1998. "The relationship among bullying, victimization, depression, anxiety, and aggression in elementary school children." Personality and individual differences 24.1: $123-130$.

Daley, Andrea, Solomon, S., and Newman, P.A. 2008. "Traversing the margins: Intersectionalities in the bullying of lesbian, gay, bisexual and transgender youth." Journal of gay \& lesbian social services 19.3-4: 9-29.

Doll, Jonathan. In Press. Ending School Shootings: A Guide to Prevention and Action.

Due, Pernille, Holstein, B.E., and Lynch, J. 2005. "Bullying and symptoms among school-aged children: international comparative cross sectional study in 28 countries." The European Journal of Public Health 15.2: 128-132.

Duncan, Neil. 1999. Sexual Bullying: Gender Conflict and Pupil Culture in Secondary Schools, Routledge, London

Eisenberg, Maria E., Dianne Neumark-Sztainer, and Cheryl L. Perry. 2003. "Peer harassment, school connectedness, and academic achievement." Journal of School Health 73.8: 311316.

Eriksen, Tine Louise Mundbjerg, Helena Skyt Nielsen, and Marianne Simonsen. 2014. "Bullying in Elementary School," Journal of Human Resources 49(4): 839-871.

Everytown.org. 2015a. "Analysis of School Shootings." Available at: http://everytown.org/documents/2014/10/analysis-of-school-shootings.pdf

Faris, Robert, and Diane Felmlee. 2011."Status struggles network centrality and gender segregation in same-and cross-gender aggression." American Sociological Review 76.1: 48-73.

Fekkes, Minne, Frans IM Pijpers, and S. Pauline Verloove-Vanhorick. 2006. "Effects of antibullying school program on bullying and health complaints." Archives of pediatrics \& adolescent medicine 160.6: 638-644.

Fleet, David D. Van and Ella W. Van Fleet. 2010. The Violence Volcano: Reducing the Threat of Workplace Violence. Information Age Publishing, Inc. Charlotte, NC.

Fox, Suzy, and Lamont E. Stallworth. 2005. "Racial/ethnic bullying: Exploring links between bullying and racism in the US workplace." Journal of Vocational Behavior 66.3: 438456.

Friedman, Mark S., Koeske, A.J., Silvestre, A.J., and Korr, W.S. 2006. "The impact of gender-role nonconforming behavior, bullying, and social support on suicidality among gay male youth."Journal of Adolescent Health 38.5: 621-623.

Gini, Gianluca, and TizianaPozzoli. 2009. "Association between bullying and psychosomatic problems: A meta-analysis." Pediatrics 123.3: 1059-1065.

Gladstone, Gemma L., Gordon B. Parker, and Gin S. Malhi. 2006. "Do bullied children become anxious and depressed adults?: A cross-sectional investigation of the correlates of bullying and anxious depression." The Journal of nervous and mental disease 194.3: 201208. 
Glew, Gwen M., Ming-Yu Fan, Wayne Katon, Frederick P. Rivara, and Mary A. Kernic. 2005.

"Bullying, psychosocial adjustment, and academic performance in elementary school."Archives of pediatrics \& adolescent medicine 159.11: 1026-1031.

Green, Jeremy Craig, Amy Estlund, Nishant Jain and Milan Patel. 2014. "Bullying Prevention Policies and Child Behavior: Evidence Using State Laws." 142nd APHA Annual Meeting and Exposition (November 15-November 19,2014).APHA.

Hansen, Benjamin and Michael Lang. 2014. "Bullying and Youth Suicide," Working Paper, University of Oregon.

Hansen, Benjamin, Daniel I. Rees, and Joseph J. Sabia. 2015. "Cigarette Taxes and Youth Smoking: Updated Estimates Using YRBS Data," NBER working paper No. 21311.

Hepburn, Lisa, Deborah Azrael, Beth Molnar, and Matthew Miller. 2012. "Bullying and suicidal behaviors among urban high school youth." Journal of Adolescent Health 51.1: 93-95.

Jeong, Seokjin, and Byung Hyun Lee. 2013. "A multilevel examination of peer victimization and bullying preventions in schools." Journal of Criminology 2013: 1, DOI: $10.1155 / 2013 / 735397$.

Juvonen, J., Graham S., Schuster, M. 2003. "Bullying among young adolescents: The strong, weak, and troubled." Pediatrics 112: 1231-1237.

Juvonen, Jaana, Yueyan Wang, and Guadalupe Espinoza. 2010. "Bullying experiences and compromised academic performance across middle school grades." The Journal of Early Adolescence 31.1: 152-173.

Kaltiala-Heino, Riittakerttu, Sari Fröjd, and Mauri Marttunen. 2010. "Involvement in bullying and depression in a 2-year follow-up in middle adolescence." European Child \& Adolescent Psychiatry 19.1: 45-55.

Kim, Young Shin, Yun-JooKoh, and Bennett Leventhal. 2005. "School bullying and suicidal risk in Korean middle school students." Pediatrics 115.2: 357-363.

Klein, Jessie. 2012. The Bully Society: school shootings and the crisis of bullying in America's schools, New York, NY: NYU Press.

Konishi, Chiaki, Shelley Hymel, Bruno D. Zumbo and Zhen Li. 2010. "Do school bullying and student-teacher relationships matter for academic achievement? A multilevel analysis." Canadian Journal of School Psychology 25.1: 19-39.

Kosciw, Joseph G., Emily A. Greytak, and Elizabeth M. Diaz. 2009. "Who, what, where, when, and why: Demographic and ecological factors contributing to hostile school climate for lesbian, gay, bisexual, and transgender youth." Journal of Youth and Adolescence 38.7: 976-988.

Kumpulainen, Kirsti, EilaRäsänen, and Irmeli Henttonen. 1999. "Children involved in bullying: psychological disturbance and the persistence of the involvement." Child abuse \& neglect 23.12: 1253-1262.

Langdon, Susan W., and William Preble. 2007. "The relationship between levels of perceived respect and bullying in 5th through 12th graders." Adolescence 43.171: 485-503.

Lieberman, Joseph. 2008. School Shootings: What Every Parent and Educator Needs to Know to Protect Our Children. New York City, New York: Kensington Publishing Corp. 
Massachusetts Advocates for Children Legislation . 2010. Section 37O. School bullying prohibited; bullying prevention plans. Available at: https://malegislature.gov/Laws/GeneralLaws/PartI/TitleXII/Chapter71/Section37O/Print

Miller, T., M. Cohen and B. Wiersema. 1996. "Victim Costs and Consequences: A New Look." Final Summary Report to the National Institute of Justice.

Minnesota Management and Budget. 2013. "Safe \& Supportive Schools Act Explanation of the Bill.” Available at: http://www.mn.gov/mmb/images/2013\%2520SF783.pdf

Nansel, Tonja R., Mary Overpeck, Ramani S. Pilla, W. June Ruan, Bruce Simons-Morton, and Peter Scheidt. 2001. "Relationships between bullying and violence among US youth." Archives of Pediatrics \& Adolescent Medicine 157.4: 348-353.

Nansel, Tonja R., Wendy Craig, Mary D. Overpeck, Gitanjali Saluja, and W. June Ruan. 2004. "Cross-national consistency in the relationship between bullying behaviors and psychosocial adjustment." Archives of Pediatrics \& Adolescent Medicine 158.8: 730-736.

National School Safety and Security Services. 2010. "School Associated Violent Deaths and School Shootings." Available at: http://www.schoolsecurity.org/trends/violent-deaths-and-school-shootings/.

$\mathrm{Ng}$, Josephine WY, and Sandra KM Tsang. 2008. "School bullying and the mental health of junior secondary school students in Hong Kong." Journal of school violence 7.2: 3-20.

O'Brennan, Lindsey M., Catherine P. Bradshaw, and Anne L. Sawyer. 2009. "Examining developmental differences in the social-emotional problems among frequent bullies, victims, and bully/victims." Psychology in the Schools 46.2: 100-115.

Oregon Revised Statutes. 2009. Section 339. Harassment, Intimidation And Bullying. Available at: http://www.oregonlaws.org/ors/chapter/339

PACER's National Bullying Prevention Center. 2014. About us. Available at: http://www.pacer.org/bullying/about/

Peters, Katie. 2013. "National Survey Reveals Parents’ Deep Concern About Protecting Kids from Violence." Center for American Progress. Retrieved on 11 Aug. 2014.

Rothon, Catherine, Jenny Head, Emily Klineberg, and Stephen Stansfeld. 2011. "Can social support protect bullied adolescents from adverse outcomes? A prospective study on the effects of bullying on the educational achievement and mental health of adolescents at secondary schools in East London." Journal of Adolescence 34.3: $579-588$.

Sabia, Joseph and Anderson, D. Mark. 2014. "Parental Involvement Laws, Birth Control, and Mental Health: New Evidence from the YRBS" Working Paper, San Diego State University.

Sabia, Joseph J., M. Melinda Pitts, and Laura Argys. 2014. "Do Minimum Wages Really Increase Youth Drinking and Drunk Driving?" Federal Reserve Bank of Atlanta Working Paper No. 2014-20.

Salmivalli, Christina, AnttiKärnä, and Elisa Poskiparta. 2011. "Counteracting bullying in Finland: The KiVa program and its effects on different forms of being bullied." International Journal of Behavioral Development 35.5: 405-411.

Saluja, Gitanjali, Ronaldo Iachan, Peter C. Scheidt, Mary D. Overpeck, Wenyu Sun, and Jay N. Giedd. 2004. "Prevalence of and risk factors for depressive symptoms among young adolescents." Archives of pediatrics \& adolescent medicine 158.8: 760-765. 
Seals, Dorothy, and Jerry Young. 2003. "Bullying and victimization: prevalence and relationship to gender, grade level, ethnicity, self-esteem, and depression." Adolescence 38.152: 735-747.

Stoptheshootings.org. 2013. "List of School Shootings." Available at: http://www.stoptheshootings.org.

Strøm, Ida Frugård, Siri Thoresen, Tore Wentzel-Larsen, and Grete Dyb. 2013. "Violence, bullying and academic achievement: A study of 15-year-old adolescents and their school environment." Child abuse \& neglect 37.4: 243-251.

Stuart-Cassel, Victoria, Ariana Bell, and J. Fred Springer. 2011. "Analysis of State Bullying Laws and Policies." Office of Planning, Evaluation and Policy Development, US Department of Education.

U.S. Department of Education. 2011. Analysis of State Bullying Laws and Policies. Retrieved from http://www2.ed.gov/rschstat/eval/bullying/state-bullying-laws/state-bullyinglaws.pdf

U.S. Department of Education, 2012. National Center for Education Statistics. 2012. Indicators of School Crime and Safety: 2011. Available at: http://www.bjs.gov/content/pub/pdf/iscs11.pdf

U.S. Department of Health and Human Services. 2014a. What Is Bullying? Retrieved on 11 Aug. 2014.

U.S. Department of Health and Human Services. 2014b. About us. Retrieved on 11 Aug. 2014.

Turner, Heather A., Jennifer Vanderminden, David Finkelhor, Sherry Hamby and Anne Shattuck. 2011. "Disability and victimization in a national sample of children and youth." Child maltreatment 16.4: 275-286.

Undheim, Anne Mari, and Anne Mari Sund. 2010. "Prevalence of bullying and aggressive behavior and their relationship to mental health problems among 12-to 15-year-old Norwegian adolescents." European child \& adolescent psychiatry 19.11: 803-811.

West, Kristina. 2014. "Public Health Approach in the Evaluation of Two States' Anti-Bullying Laws and Local School District Policies." Working Paper, George Washington University.

Wilkins-Shurmer, Amanda, Mj O'Callaghan, J. M. Najman, William Bor, G. M. Williams, and M. J. Anderson. 2003. "Association of bullying with adolescent health-related quality of life." Journal of pediatrics and child health 39.6: 436-441.

Wolke, Dieter, William E. Copeland, Adrian Angold, and E. Jane Costello. 2013. "Impact of bullying in childhood on adult health, wealth, crime, and social outcomes." Psychological science 24.10: 1958-1970. 
Figure 1. Trends in Student Safety, YRBS

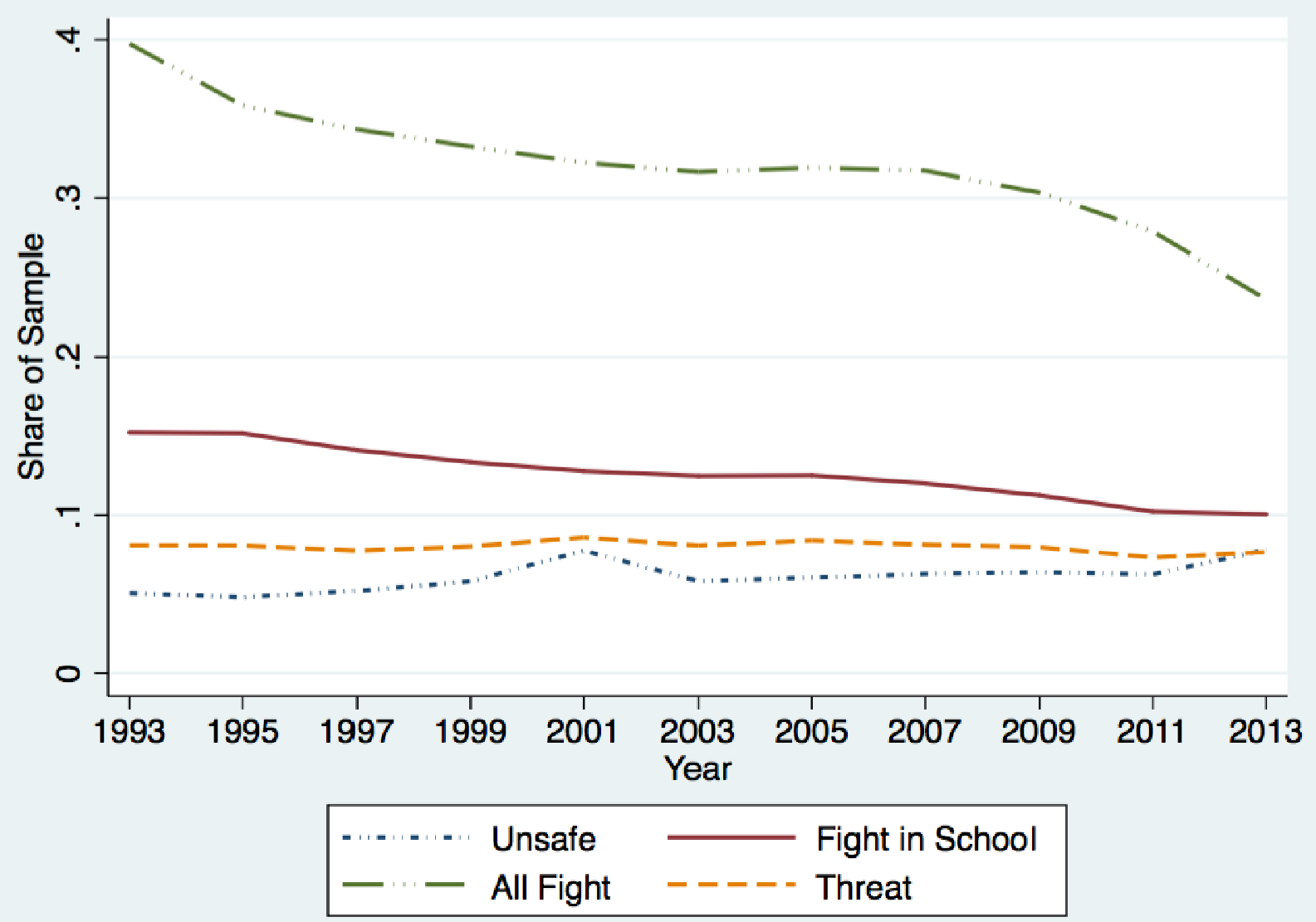

Notes: Unweighted treands are obtained using data from the National and State YRBS between 1993 and 2013. 
Table 1. Means of Outcomes and Key Control Variables, by Data Source

\begin{tabular}{|c|c|c|c|}
\hline & Mean (StD) [N] & Source & Years \\
\hline \multicolumn{4}{|l|}{ Dependent Variables } \\
\hline Unsafe & $0.063(0.243)[1,105,255]$ & YRBS & $1993-2013$ \\
\hline Fight in School & $0.122(0.327)[1,054,461]$ & YRBS & $1993-2013$ \\
\hline All Fight & $0.312(0.463)[1,031,970]$ & YRBS & $1993-2013$ \\
\hline Threat & $0.080(0.271)[1,070,208]$ & YRBS & $1993-2013$ \\
\hline Bullied & $0.201(0.401)[412,666]$ & YRBS & 2009-2013 \\
\hline Not Attending High School & $0.146(0.353)[1,415,700]$ & CPS & $1993-2013$ \\
\hline Violent Crime $^{a}$ (Ages 13-17) & $325.24(232.45)[979]$ & FBI Uniform Crime Reports & $1993-2012$ \\
\hline Violent Crime $^{\mathrm{a}}$ (Ages 20-24) & $418.76(234.45)[980]$ & FBI Uniform Crime Reports & 1993-2012 \\
\hline Property Crime $^{\mathrm{a}}$ (Ages 13-17) & $1,999.90(1,060.77)[981]$ & FBI Uniform Crime Reports & $1993-2012$ \\
\hline Property Crime $^{a}$ (Ages 20-24) & $1,163.62(451.96)[981]$ & FBI Uniform Crime Reports & 1993-2012 \\
\hline Fear (Ages 20-24) & $0.398(0.276)\left[1,113^{\mathrm{b}}\right]$ & GSS & 1993-2009 \\
\hline Shotgun (Ages 20-24) & $0.161(0.201)\left[1,106^{\mathrm{b}}\right]$ & GSS & 1993-2009 \\
\hline Not Wear Helmet & $0.897(0.304)[653,327]$ & YRBS & $1993-2013$ \\
\hline Teen Shooting Involving Death & $0.104(0.305)[1,020]$ & National School Safety Center & $1993-2012$ \\
\hline Older Shooting Involving Death & $0.024(0.152)[1,020]$ & National School Safety Center & 1993-2012 \\
\hline Teen Shooting Involving Homicide & $0.060(0.237)[1,020]$ & National School Safety Center & 1993-2012 \\
\hline Older Shooting Involving Homicide & $0.017(0.128)[1,020]$ & National School Safety Center & 1993-2012 \\
\hline \multicolumn{4}{|l|}{ Anti-Bullying Laws } \\
\hline $\mathrm{ABL}$ & $0.365(0.472)$ & Department of Education & $1993-2013$ \\
\hline ABL with Model Policy & $0.315(0.458)$ & Department of Education & $1993-2013$ \\
\hline ABL without Model Policy & $0.049(0.211)$ & Department of Education & $1993-2013$ \\
\hline High Intensity ABL & $0.139(0.344)$ & Department of Education & $1993-2013$ \\
\hline Moderate Intensity ABL & $0.172(0.370)$ & Department of Education & $1993-2013$ \\
\hline Low Intensity ABL & $0.054(0.221)$ & Department of Education & $1993-2013$ \\
\hline High Intensity District Policy & $0.155(0.357)$ & Department of Education & $1993-2013$ \\
\hline Moderate Intensity District Policy & $0.151(0.354)$ & Department of Education & $1993-2013$ \\
\hline Low Intensity District Policy & $0.059(0.230)$ & Department of Education & $1993-2013$ \\
\hline Written Records \& Reporting & $0.051(0.216)$ & Department of Education & $1993-2013$ \\
\hline Investigations & $0.105(0.306)$ & Department of Education & $1993-2013$ \\
\hline
\end{tabular}




\begin{tabular}{|c|c|c|c|}
\hline & Mean (StD) [N] & Source & Years \\
\hline Consequences & $0.203(0.395)$ & Department of Education & $1993-2013$ \\
\hline Communications \& Transparency & $0.081(0.271)$ & Department of Education & $1993-2013$ \\
\hline Legal Definitions & $0.204(0.397)$ & Department of Education & $1993-2013$ \\
\hline 4 or more Components & $0.041(0.197)$ & Department of Education & $1993-2013$ \\
\hline 2 or 3 Components & $0.166(0.368)$ & Department of Education & $1993-2013$ \\
\hline Less than 2 Components & $0.157(0.357)$ & Department of Education & $1993-2013$ \\
\hline \multicolumn{4}{|l|}{ Demographic Controls } \\
\hline Age & $15.96(1.259)$ & YRBS & $1993-2013$ \\
\hline Male & $0.491(0.500)$ & YRBS & $1993-2013$ \\
\hline White & $0.590(0.492)$ & YRBS & $1993-2013$ \\
\hline Black & $0.152(0.359)$ & YRBS & $1993-2013$ \\
\hline Grade & $10.35(1.122)$ & YRBS & $1993-2013$ \\
\hline \multicolumn{4}{|l|}{ State-Specific Education Controls } \\
\hline National School Lunch Participation Rate & $0.098(0.019)$ & US Department of Agriculture & $1993-2013$ \\
\hline Average Student-Teacher Ratio & $14.62(2.870)$ & NCES Digest of Education Statistics & $1993-2013$ \\
\hline Average Teacher Salary (in thousands of 2013\$) & $56.47(9.196)$ & NCES Digest of Education Statistics & $1993-2013$ \\
\hline Share of Population with Bachelor's Degree & $0.281(0.061)$ & Current Population Survey & $1993-2013$ \\
\hline Zero Tolerance School Violence Law & $0.932(0.239)$ & Education Commission of the States & $1993-2013$ \\
\hline \multicolumn{4}{|l|}{ State-Specific Economic and Policy Controls } \\
\hline Police expenditures per 1,000 population & $243.96(95.94)$ & Bureau of Justice Statistics & $1993-2013$ \\
\hline Law enforcement employees per 1,000 population & $2.260(0.062)$ & Bureau of Justice Statistics & $1993-2013$ \\
\hline CAP law & $0.464(0.497)$ & Law Center to Prevent Gun Violence & $1993-2013$ \\
\hline Shall Issue Law & $0.632(0.482)$ & Law Center to Prevent Gun Violence & $1993-2013$ \\
\hline Zero Tolerance Drunk Driving Laws & $0.910(0.275)$ & Updated from Anderson et al. (2013) & $1993-2013$ \\
\hline Cigarette Taxes $(2013 \$)$ & $1.164(0.928)$ & Tax Burden on Tobacco & $1993-2013$ \\
\hline Beer taxes $(2013 \$)$ & $0.300(0.228)$ & Beer Institute & $1993-2013$ \\
\hline Unemployment Rates & $0.061(0.020)$ & Bureau of Labor Statistics & $1993-2013$ \\
\hline Per Capita Income (in thousands of $2013 \$$ ) & $41.13(7.347)$ & US Census Bureau & $1993-2013$ \\
\hline
\end{tabular}

Notes: Standard deviations are in parentheses and sample sizes are in brackets.

${ }^{\mathrm{a}}$ Crime rates are arrest rates per 100,000 population of the appropriate ages.

${ }^{\mathrm{b}}$ Individuals used to estimate the state-by-year regressions. 
Table 2. State Anti-Bullying Laws (ABL), 1993-2013 ${ }^{1,2}$

\begin{tabular}{|c|c|c|c|c|c|c|c|}
\hline State & $\begin{array}{l}\text { Effective Date } \\
\text { of School } \\
\text { District Policy }\end{array}$ & $\begin{array}{c}\text { DOE } \\
\text { Intensity } \\
\text { Rating }\end{array}$ & $\begin{array}{c}\text { Written } \\
\text { Records \& } \\
\text { Reporting }\end{array}$ & Investigations & Consequences & $\begin{array}{c}\text { Training \& } \\
\text { Transparency }\end{array}$ & $\begin{array}{c}\text { Legal } \\
\text { Definitions }\end{array}$ \\
\hline $\mathrm{AL}$ & 07/01/2010 & 20 & & $\mathrm{X}$ & & & $X$ \\
\hline AK & 07/01/2007 & 10 & & & & & \\
\hline $\mathrm{AZ}$ & 08/12/2005 & 13 & X & & & & \\
\hline AR & $07 / 16 / 2003$ & 21 & & & & & $X$ \\
\hline CA & $01 / 01 / 2004$ & 17 & & & $\mathrm{X}$ & & \\
\hline $\mathrm{CO}$ & 08/08/2001 & 11 & & & $\mathrm{X}$ & & $\mathrm{X}$ \\
\hline CT & 02/01/2009 & 22 & $X$ & $X$ & $\mathrm{X}$ & $X$ & \\
\hline DC & $06 / 22 / 2012$ & 22 & $X$ & $X$ & $\mathrm{X}$ & & \\
\hline $\mathrm{DE}$ & 01/01/2008 & 22 & & & $X$ & $\mathrm{X}$ & $X$ \\
\hline FL & $12 / 01 / 2008$ & 24 & & $\mathrm{X}$ & $X$ & & $X$ \\
\hline GA & 08/01/2011 & 13 & & & $\mathrm{X}$ & & \\
\hline HI & 07/11/2011 & 12 & $X$ & $X$ & $\mathrm{X}$ & & \\
\hline ID & 07/01/2006 & 06 & & & & & \\
\hline $\mathrm{IL}^{\mathrm{a}}$ & $06 / 28 / 2010$ & 16 & & & $\mathrm{X}$ & & \\
\hline IN & 07/01/2005 & 08 & & & & & \\
\hline IA & 09/01/2007 & 19 & & & & & $\mathrm{X}$ \\
\hline KS & 07/01/2008 & 06 & & & & & \\
\hline KY & $11 / 30 / 2008$ & 15 & & $\mathrm{X}$ & $\mathrm{X}$ & & \\
\hline LA & 08/01/2001 & 17 & & & & & \\
\hline ME & 09/01/2006 & 20 & & & $\mathrm{X}$ & & $\mathrm{X}$ \\
\hline MD & 07/01/2009 & 28 & & & $\mathrm{X}$ & $\mathrm{X}$ & $\mathrm{X}$ \\
\hline MA & $12 / 31 / 2010$ & 23 & & $\mathrm{X}$ & $\mathrm{X}$ & & \\
\hline MI & $06 / 07 / 2012$ & 28 & $X$ & $\mathrm{X}$ & $\mathrm{X}$ & $\mathrm{X}$ & \\
\hline MN & 08/01/2007 & 03 & & & & & \\
\hline MS & $12 / 31 / 2010$ & 11 & & & & & \\
\hline MO & 09/01/2007 & 10 & & & & & \\
\hline $\mathrm{MT}^{\mathrm{b}}$ & No Law & - & - & - & - & - & - \\
\hline $\mathrm{NE}$ & 07/01/2009 & 06 & & & & & \\
\hline $\mathrm{NV}$ & $07 / 01 / 2005$ & 19 & & & & & $\mathrm{X}$ \\
\hline $\mathrm{NH}$ & 01/01/2011 & 27 & & $\mathrm{X}$ & $\mathrm{X}$ & $\mathrm{X}$ & $\mathrm{X}$ \\
\hline NJ & 09/01/2011 & 30 & $\mathrm{X}$ & $\mathrm{X}$ & $\mathrm{X}$ & $\mathrm{X}$ & $\mathrm{X}$ \\
\hline NM & $04 / 01 / 2007$ & 16 & & & & & \\
\hline$N Y^{c}$ & 07/01/2013 & 20 & & & $X$ & & $X$ \\
\hline $\mathrm{NC}$ & $12 / 31 / 2009$ & 20 & & & & & $\mathrm{X}$ \\
\hline ND & $07 / 01 / 2012$ & 20 & & $\mathrm{X}$ & & & $\mathrm{X}$ \\
\hline $\mathrm{OH}$ & 09/29/2010 & 18 & & $\mathrm{X}$ & & & $\mathrm{X}$ \\
\hline OK & $11 / 01 / 2002$ & 14 & & & & & \\
\hline OR & $01 / 01 / 2004$ & 21 & & $\mathrm{X}$ & & & \\
\hline
\end{tabular}




\begin{tabular}{|c|c|c|c|c|c|c|c|}
\hline State & $\begin{array}{c}\text { Effective Date } \\
\text { of School } \\
\text { District Policy }\end{array}$ & $\begin{array}{c}\text { DOE } \\
\text { Intensity } \\
\text { Rating }\end{array}$ & $\begin{array}{c}\text { Written } \\
\text { Records \& } \\
\text { Reporting }\end{array}$ & Investigations & Consequences & $\begin{array}{c}\text { Training \& } \\
\text { Transparency }\end{array}$ & $\begin{array}{c}\text { Legal } \\
\text { Definitions }\end{array}$ \\
\hline PA & $01 / 01 / 2009$ & 13 & & & & & \\
\hline RI & 09/01/2004 & 14 & & & & & \\
\hline $\mathrm{SC}$ & 01/01/2007 & 19 & & $\mathrm{X}$ & & & $X$ \\
\hline $\mathrm{SD}$ & 07/01/2012 & 07 & & & $X$ & & \\
\hline $\mathrm{TN}$ & 01/01/2006 & 14 & & $\mathrm{X}$ & & & $X$ \\
\hline $\mathrm{TX}$ & 06/17/2011 & 05 & & & $X$ & & \\
\hline UT & 09/01/2012 & 13 & & & & & $X$ \\
\hline VT & $01 / 15 / 2007$ & 22 & $X$ & $X$ & $X$ & & $X$ \\
\hline VA & 07/01/2013 & 18 & & & $X$ & & \\
\hline WA & 08/01/2011 & 30 & $X$ & $\mathrm{X}$ & $X$ & & \\
\hline WV & $12 / 01 / 2001$ & 23 & & $\mathrm{X}$ & & & $X$ \\
\hline WI & 08/15/2010 & 09 & & & & & \\
\hline WY & $12 / 31 / 2009$ & 19 & & $X$ & & & $X$ \\
\hline
\end{tabular}

Note: 48 states that have implemented an ABL, except for Hawaii and the District of Columbia, contribute

identifying variation in the YRBS sample. Besides the above state, Hawaii also contributes to identifying variation in the Uniform Crime Reports sample.

${ }^{a}$ While Illinois's 2006 Senate Bill 2630 encouraged school district to adopt anti-bullying policies, the state's 2010 Senate Bill 3266 was the first anti-bullying law to require school district anti-bullying policies.

${ }^{\mathrm{b}}$ Montana passed an ABL in April 2015.

c New York's Dignity for All Students Act was first enacted in 2010 and became effective in 2012. However, the mandates on school district policies were specified in details in the Act's Amendment which took effect in 2013. 


\section{Table 3: Difference-in-Difference Estimates of Relationship between Anti-Bullying Laws and School Safety}

\begin{tabular}{|c|c|c|c|c|}
\hline & $\begin{array}{c}\text { Unsafe } \\
\text { (1) }\end{array}$ & $\begin{array}{c}\text { Fight in } \\
\text { School } \\
(2)\end{array}$ & $\begin{array}{c}\text { All Fight } \\
\text { (3) }\end{array}$ & $\begin{array}{c}\text { Threat } \\
\text { (4) }\end{array}$ \\
\hline & \multicolumn{4}{|c|}{ Panel I: Baseline Difference-in-Difference } \\
\hline \multirow[t]{2}{*}{$\mathrm{ABL}$} & $\begin{array}{c}0.001 \\
(0.004)\end{array}$ & $\begin{array}{c}0.002 \\
(0.003)\end{array}$ & $\begin{array}{c}0.003 \\
(0.005)\end{array}$ & $\begin{array}{c}0.000 \\
(0.003)\end{array}$ \\
\hline & \multicolumn{4}{|c|}{$\begin{array}{c}\text { Panel II: Panel I + Individual \& State Economic } \\
\text { Controls }\end{array}$} \\
\hline \multirow[t]{2}{*}{ ABL } & $\begin{array}{c}0.001 \\
(0.003)\end{array}$ & $\begin{array}{c}0.000 \\
(0.003)\end{array}$ & $\begin{array}{c}0.002 \\
(0.005)\end{array}$ & $\begin{array}{c}0.000 \\
(0.002)\end{array}$ \\
\hline & \multicolumn{4}{|c|}{ Panel III: Panel II + State Policy \& Education Controls } \\
\hline \multirow[t]{2}{*}{$\mathrm{ABL}$} & $\begin{array}{c}0.000 \\
(0.003)\end{array}$ & $\begin{array}{c}0.000 \\
(0.002)\end{array}$ & $\begin{array}{c}0.000 \\
(0.004)\end{array}$ & $\begin{array}{l}-0.000 \\
(0.002)\end{array}$ \\
\hline & \multicolumn{4}{|c|}{ Panel IV: Leads and Lags of ABL } \\
\hline 3 Years Before & $\begin{array}{l}-0.004 \\
(0.004)\end{array}$ & $\begin{array}{c}-0.009 * * * \\
(0.003)\end{array}$ & $\begin{array}{c}-0.016^{* *} \\
(0.008)\end{array}$ & $\begin{array}{l}-0.004 \\
(0.003)\end{array}$ \\
\hline 2 Years Before & $\begin{array}{l}-0.004 \\
(0.004)\end{array}$ & $\begin{array}{l}0.006^{* *} \\
(0.003)\end{array}$ & $\begin{array}{c}0.000 \\
(0.004)\end{array}$ & $\begin{array}{c}0.003 \\
(0.003)\end{array}$ \\
\hline 1 Year Before & $\begin{array}{c}0.001 \\
(0.005)\end{array}$ & $\begin{array}{l}-0.003 \\
(0.004)\end{array}$ & $\begin{array}{l}-0.007 \\
(0.006)\end{array}$ & $\begin{array}{l}-0.001 \\
(0.004)\end{array}$ \\
\hline Year of Law Change & $\begin{array}{l}-0.004 \\
(0.004)\end{array}$ & $\begin{array}{c}0.002 \\
(0.003)\end{array}$ & $\begin{array}{c}0.001 \\
(0.005)\end{array}$ & $\begin{array}{c}0.002 \\
(0.004)\end{array}$ \\
\hline 1 Year After & $\begin{array}{c}0.001 \\
(0.005)\end{array}$ & $\begin{array}{l}-0.004 \\
(0.006)\end{array}$ & $\begin{array}{l}-0.016 \\
(0.011)\end{array}$ & $\begin{array}{l}-0.001 \\
(0.005)\end{array}$ \\
\hline 2 Years After & $\begin{array}{l}-0.002 \\
(0.004)\end{array}$ & $\begin{array}{c}0.004 \\
(0.005)\end{array}$ & $\begin{array}{c}0.007 \\
(0.007)\end{array}$ & $\begin{array}{c}0.001 \\
(0.004)\end{array}$ \\
\hline $3+$ Years After & $\begin{array}{l}-0.001 \\
(0.005)\end{array}$ & $\begin{array}{l}-0.003 \\
(0.007)\end{array}$ & $\begin{array}{l}-0.013 \\
(0.008)\end{array}$ & $\begin{array}{l}-0.002 \\
(0.004)\end{array}$ \\
\hline \multirow[t]{2}{*}{$\chi^{2}$ of $\sum\left(\beta_{\text {yrchange }}, \beta_{\text {lags }}\right)=0$ (p-value $)$} & $\begin{array}{l}0.61(0.43) \\
0.18(0.67)\end{array}$ & $\begin{array}{l}0.78(0.38) \\
0.00(0.96)\end{array}$ & $\begin{array}{l}3.04(0.08) \\
0.81(0.37)\end{array}$ & $\begin{array}{l}0.07(0.79) \\
0.00(0.98)\end{array}$ \\
\hline & \multicolumn{4}{|c|}{ Panel V: Panel III + State Linear Trends } \\
\hline $\mathrm{ABL}$ & $\begin{array}{c}0.001 \\
(0.003)\end{array}$ & $\begin{array}{c}0.001 \\
(0.003)\end{array}$ & $\begin{array}{c}0.003 \\
(0.004)\end{array}$ & $\begin{array}{l}-0.001 \\
(0.003)\end{array}$ \\
\hline State FE? & Yes & Yes & Yes & Yes \\
\hline Year FE? & Yes & Yes & Yes & Yes \\
\hline Controls? & Yes & Yes & Yes & Yes \\
\hline $\mathrm{N}$ & $1,105,255$ & $1,054,461$ & $1,031,970$ & $1,070,208$ \\
\hline
\end{tabular}


Table 4: Exploring Heterogeneity in the Effects of ABL by Department of Education Intensity Rating

\begin{tabular}{|c|c|c|c|c|}
\hline & $\begin{array}{c}\text { Unsafe } \\
\text { (1) }\end{array}$ & $\begin{array}{l}\text { Fight in } \\
\text { School } \\
(2)\end{array}$ & $\begin{array}{l}\text { All Fight } \\
\text { (3) }\end{array}$ & $\begin{array}{c}\text { Threat } \\
\text { (4) }\end{array}$ \\
\hline & \multicolumn{4}{|c|}{ Panel I: Model Policy } \\
\hline \multirow[t]{2}{*}{ ABL with Model Policy } & 0.001 & -0.000 & 0.002 & 0.000 \\
\hline & $(0.003)$ & $(0.003)$ & $(0.005)$ & $(0.003)$ \\
\hline \multirow{2}{*}{ ABL without Model Policy } & 0.000 & 0.005 & 0.006 & -0.006 \\
\hline & $(0.007)$ & $(0.005)$ & $(0.011)$ & $(0.004)$ \\
\hline \multirow[t]{2}{*}{$\chi^{2}$ of $\beta_{\mathrm{MP}}=\beta_{\mathrm{No} M P}(\mathrm{p}-\mathrm{value})$} & $0.01(0.93)$ & $0.94(0.33)$ & $0.12(0.73)$ & $2.11(0.15)$ \\
\hline & \multicolumn{4}{|c|}{ Panel II: Intensity Rating } \\
\hline \multirow[t]{2}{*}{ High Intensity ABL } & -0.001 & $-0.011 * *$ & -0.006 & -0.003 \\
\hline & $(0.006)$ & $(0.005)$ & $(0.006)$ & $(0.006)$ \\
\hline \multirow[t]{2}{*}{ Moderate Intensity ABL } & 0.000 & 0.004 & 0.007 & 0.000 \\
\hline & $(0.004)$ & $(0.004)$ & $(0.006)$ & $(0.003)$ \\
\hline \multirow[t]{2}{*}{ Low Intensity ABL } & 0.004 & 0.009 & 0.005 & -0.001 \\
\hline & $(0.005)$ & $(0.006)$ & $(0.008)$ & $(0.005)$ \\
\hline$\chi^{2}$ of $\beta_{\text {High }}=\beta_{\text {Moderate }}(p$-value $)$ & $0.02(0.89)$ & $5.76(0.02)$ & $3.00(0.08)$ & $0.24(0.63)$ \\
\hline \multirow{2}{*}{$\chi^{2}$ of $\beta_{\text {High }}=\beta_{\text {Low }}(p-$ value $)$} & $0.26(0.61)$ & $6.28(0.01)$ & $1.24(0.26)$ & $0.09(0.77)$ \\
\hline & \multicolumn{4}{|c|}{ Panel III: School District Policy Intensity Rating } \\
\hline \multirow[t]{2}{*}{ High Intensity District Policy } & -0.000 & $-0.008 *$ & -0.002 & -0.001 \\
\hline & $(0.005)$ & $(0.004)$ & $(0.005)$ & $(0.005)$ \\
\hline \multirow[t]{2}{*}{ Moderate Intensity District Policy } & 0.000 & 0.007 & 0.009 & -0.000 \\
\hline & $(0.004)$ & $(0.004)$ & $(0.007)$ & $(0.003)$ \\
\hline \multirow[t]{2}{*}{ Low Intensity District Policy } & 0.004 & 0.008 & 0.003 & -0.001 \\
\hline & $(0.005)$ & $(0.006)$ & $(0.008)$ & $(0.005)$ \\
\hline$\chi^{2}$ of $\beta_{\text {High }}=\beta_{\text {Moderate }}(p$-value $)$ & $0.00(0.96)$ & $5.91(0.02)$ & $1.78(0.18)$ & $0.03(0.87)$ \\
\hline \multirow{2}{*}{$\chi^{2}$ of $\beta_{\text {High }}=\beta_{\text {Low }}(p-$ value $)$} & $0.45(0.50)$ & $4.75(0.03)$ & $0.26(0.61)$ & $0.00(0.99)$ \\
\hline & \multicolumn{4}{|c|}{ Panel IV: Individual High Intensity Components } \\
\hline \multirow[t]{2}{*}{ Written Records \& Reporting } & $-0.014 *$ & $-0.016^{* *}$ & -0.012 & $-0.020 * * *$ \\
\hline & $(0.008)$ & $(0.007)$ & $(0.010)$ & $(0.005)$ \\
\hline \multirow[t]{2}{*}{ Investigations } & 0.008 & -0.007 & 0.002 & -0.000 \\
\hline & $(0.005)$ & $(0.005)$ & $(0.008)$ & $(0.005)$ \\
\hline \multirow[t]{2}{*}{ Consequences } & 0.002 & 0.001 & 0.001 & -0.000 \\
\hline & $(0.005)$ & $(0.005)$ & $(0.009)$ & $(0.004)$ \\
\hline \multirow[t]{2}{*}{ Training \& Transparency } & 0.006 & 0.010 & -0.004 & $0.019 * * *$ \\
\hline & $(0.010)$ & $(0.007)$ & $(0.008)$ & $(0.004)$ \\
\hline \multirow[t]{2}{*}{ Legal Definitions } & -0.007 & 0.001 & 0.002 & 0.000 \\
\hline & $(0.005)$ & $(0.004)$ & $(0.007)$ & $(0.004)$ \\
\hline
\end{tabular}




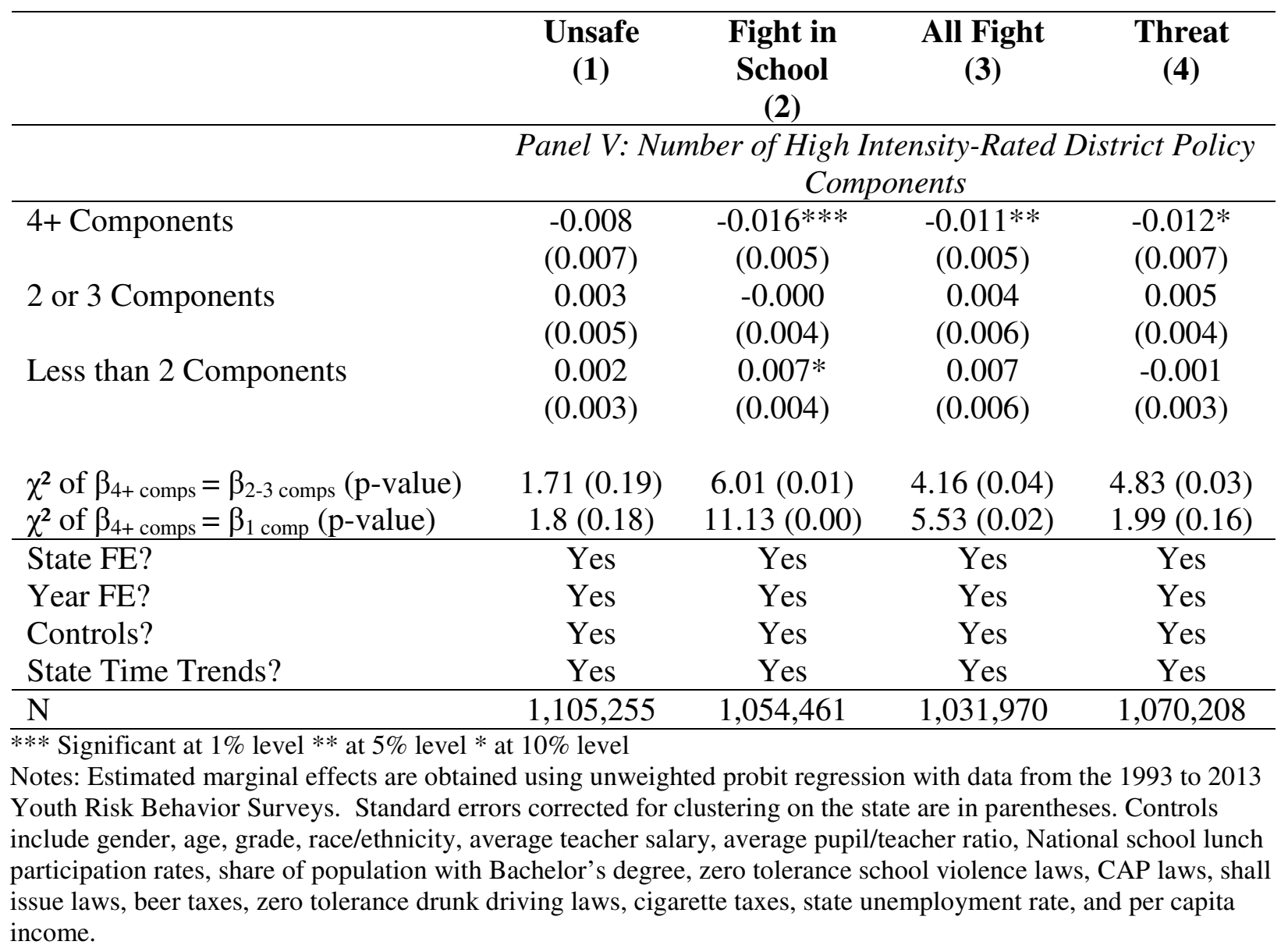


Table 6: Difference-in-Difference Estimates of Relationship between ABLs and Bullying

\begin{tabular}{|c|c|c|c|}
\hline & (1) & (2) & (3) \\
\hline & \multicolumn{3}{|c|}{ Panel I: Any ABL } \\
\hline \multirow[t]{3}{*}{$\mathrm{ABL}$} & $-0.009 *$ & -0.009 & -0.008 \\
\hline & $(0.005)$ & $(0.007)$ & $(0.006)$ \\
\hline & \multicolumn{3}{|c|}{ Panel II: Model Policy } \\
\hline \multirow[t]{2}{*}{ ABL with Model Policy } & -0.008 & -0.007 & -0.008 \\
\hline & $(0.006)$ & $(0.008)$ & $(0.007)$ \\
\hline \multirow[t]{2}{*}{ ABL without Model Policy } & $-0.016^{*}$ & $-0.020 * * *$ & -0.014 \\
\hline & $(0.009)$ & $(0.007)$ & $(0.009)$ \\
\hline \multirow{2}{*}{$\chi^{2}$ of $\beta_{\mathrm{MP}}=\beta_{\text {No MP }}(p-$ value $)$} & $0.57(0.45)$ & $2.40(0.12)$ & $0.35(0.56)$ \\
\hline & \multicolumn{3}{|c|}{ Panel III: Intensity Rating } \\
\hline \multirow[t]{2}{*}{ High Intensity ABL } & $-0.018 *$ & $-0.017 *$ & $-0.019 *$ \\
\hline & $(0.010)$ & $(0.010)$ & $(0.010)$ \\
\hline \multirow[t]{2}{*}{ Moderate Intensity ABL } & -0.007 & -0.007 & -0.006 \\
\hline & $(0.008)$ & $(0.012)$ & $(0.010)$ \\
\hline \multirow[t]{2}{*}{ Low Intensity ABL } & -0.008 & -0.008 & -0.007 \\
\hline & $(0.006)$ & $(0.006)$ & $(0.007)$ \\
\hline$\chi^{2}$ of $\beta_{\text {High }}=\beta_{\text {Moderate }}(p$-value $)$ & $0.75(0.39)$ & $0.40(0.53)$ & $0.70(0.40)$ \\
\hline \multirow[t]{2}{*}{$\chi^{2}$ of $\beta_{\text {High }}=\beta_{\text {Low }}(p-$ value $)$} & $0.84(0.36)$ & $0.67(0.41)$ & $1.01(0.32)$ \\
\hline & \multicolumn{3}{|c|}{ Panel IV: School District Policy Intensity Rating } \\
\hline \multirow[t]{2}{*}{ High Intensity District Policy } & -0.006 & -0.007 & -0.006 \\
\hline & $(0.006)$ & $(0.008)$ & $(0.007)$ \\
\hline \multirow[t]{2}{*}{ Moderate Intensity District Policy } & -0.017 & -0.013 & -0.015 \\
\hline & $(0.017)$ & $(0.021)$ & $(0.018)$ \\
\hline \multirow[t]{2}{*}{ Low Intensity District Policy } & -0.008 & -0.008 & -0.007 \\
\hline & $(0.006)$ & $(0.005)$ & $(0.007)$ \\
\hline$\chi^{2}$ of $\beta_{\text {High }}=\beta_{\text {Moderate }}(p$-value $)$ & $0.41(0.52)$ & $0.06(0.87)$ & $0.22(0.64)$ \\
\hline \multirow[t]{2}{*}{$\chi^{2}$ of $\beta_{\text {High }}=\beta_{\text {Low }}(p-$ value $)$} & $0.08(0.78)$ & $0.00(0.96)$ & $0.01(0.92)$ \\
\hline & Panel V: Inc & al High Inter & Components \\
\hline \multirow[t]{2}{*}{ Written Records \& Reporting } & 0.008 & 0.017 & 0.013 \\
\hline & $(0.020)$ & $(0.022)$ & $(0.017)$ \\
\hline \multirow[t]{2}{*}{ Investigations } & -0.013 & $-0.025 * *$ & -0.018 \\
\hline & $(0.010)$ & $(0.013)$ & $(0.012)$ \\
\hline \multirow[t]{2}{*}{ Consequences } & $-0.022 *$ & -0.019 & $-0.019 *$ \\
\hline & $(0.012)$ & $(0.013)$ & $(0.012)$ \\
\hline \multirow[t]{2}{*}{ Training \& Transparency } & 0.018 & 0.017 & 0.014 \\
\hline & $(0.024)$ & $(0.025)$ & $(0.021)$ \\
\hline \multirow[t]{2}{*}{ Legal Definitions } & 0.012 & $0.017^{*}$ & 0.015 \\
\hline & $(0.009)$ & $(0.011)$ & $(0.012)$ \\
\hline
\end{tabular}

Panel VI: Number of High Intensity-Rated District Policy Components 


\begin{tabular}{lccc}
\hline & $\mathbf{( 1 )}$ & $\mathbf{( 2 )}$ & $\mathbf{( 3 )}$ \\
\hline 4+ Components & -0.003 & -0.005 & -0.005 \\
& $(0.005)$ & $(0.004)$ & $(0.005)$ \\
2 or 3 Components & -0.007 & -0.010 & -0.008 \\
& $(0.009)$ & $(0.013)$ & $(0.012)$ \\
Less than 2 Components & -0.013 & -0.010 & -0.010 \\
& $(0.009)$ & $(0.011)$ & $(0.008)$ \\
$\chi^{2}$ of $\beta_{4+\text { comps }}=\beta_{2-3 \text { comps }}(p-v a l u e)$ & & & \\
$\chi^{2}$ of $\beta_{4+\text { comps }}=\beta_{1 \text { comp }}(\mathrm{p}$-value) & $0.15(0.70)$ & $0.19(0.67)$ & $0.05(0.82)$ \\
State FE? & $0.95(0.33)$ & $0.31(0.58)$ & $0.31(0.58)$ \\
Year FE? & Yes & Yes & Yes \\
Individual \& state economic controls? & No & Yes & Yes \\
State policy \& education controls? & No & No & Yes \\
\hline $\mathrm{N}$ & 412,666 & 412,666 & Yes \\
\hline
\end{tabular}

*** Significant at $1 \%$ level $* *$ at $5 \%$ level * at $10 \%$ level

Notes: Estimated marginal effects are obtained using unweighted probit regression with data from the 1993 to 2013 Youth Risk Behavior Surveys. Standard errors corrected for clustering on the state are in parentheses. Controls include gender, age, grade, race/ethnicity, average teacher salary, average pupil/teacher ratio, National school lunch participation rates, share of population with Bachelor's degree, zero tolerance school violence laws, CAP laws, shall issue laws, beer taxes, zero tolerance drunk driving laws, cigarette taxes, state unemployment rate, and per capita income. 
Table 7: Difference-in-Difference Estimates of Relationship between ABLs and the Probability of Not Attending High School

\begin{tabular}{|c|c|c|c|}
\hline & (1) & (2) & (3) \\
\hline & \multicolumn{3}{|c|}{ Panel I: $A B L$} \\
\hline \multirow[t]{3}{*}{$\mathrm{ABL}$} & -0.001 & -0.001 & -0.001 \\
\hline & $(0.003)$ & $(0.003)$ & $(0.003)$ \\
\hline & \multicolumn{3}{|c|}{ Panel II: Model Policy } \\
\hline \multirow[t]{2}{*}{ ABL with Model Policy } & 0.000 & -0.000 & -0.000 \\
\hline & $(0.003)$ & $(0.003)$ & $(0.003)$ \\
\hline \multirow{2}{*}{ ABL without Model Policy } & -0.004 & -0.006 & -0.006 \\
\hline & $(0.006)$ & $(0.006)$ & $(0.007)$ \\
\hline \multirow[t]{2}{*}{$\chi^{2}$ of $\beta_{\mathrm{MP}}=\beta_{\text {No MP }}(p$-value $)$} & $0.39(0.53)$ & $0.80(0.37)$ & $0.63(0.43)$ \\
\hline & \multicolumn{3}{|c|}{ Panel III: Intensity Rating } \\
\hline \multirow[t]{2}{*}{ High Intensity ABL } & -0.005 & -0.004 & -0.004 \\
\hline & $(0.004)$ & $(0.004)$ & $(0.004)$ \\
\hline \multirow[t]{2}{*}{ Moderate Intensity ABL } & 0.001 & 0.000 & 0.000 \\
\hline & $(0.004)$ & $(0.003)$ & $(0.003)$ \\
\hline \multirow{2}{*}{ Low Intensity ABL } & 0.001 & -0.001 & -0.002 \\
\hline & $(0.007)$ & $(0.007)$ & $(0.007)$ \\
\hline$\chi^{2}$ of $\beta_{\text {High }}=\beta_{\text {Moderate }}(p$-value $)$ & $1.23(0.27)$ & $0.67(0.41)$ & $0.77(0.38)$ \\
\hline \multirow[t]{2}{*}{$\chi^{2}$ of $\beta_{\text {High }}=\beta_{\text {Low }}(p$-value $)$} & $0.62(0.43)$ & $0.13(0.72)$ & $0.09(0.77)$ \\
\hline & \multicolumn{3}{|c|}{ Panel IV: School District Policy Intensity Rating } \\
\hline \multirow[t]{2}{*}{ High Intensity District Policy } & -0.001 & -0.000 & -0.000 \\
\hline & $(0.004)$ & $(0.004)$ & $(0.004)$ \\
\hline \multirow[t]{2}{*}{ Moderate Intensity District Policy } & -0.001 & -0.002 & -0.002 \\
\hline & $(0.004)$ & $(0.004)$ & $(0.004)$ \\
\hline \multirow[t]{2}{*}{ Low Intensity District Policy } & 0.001 & -0.001 & -0.002 \\
\hline & $(0.007)$ & $(0.007)$ & $(0.007)$ \\
\hline$\chi^{2}$ of $\beta_{\text {High }}=\beta_{\text {Moderate }}(p$-value $)$ & $0.00(0.98)$ & $0.05(0.82)$ & $0.11(0.74)$ \\
\hline \multirow[t]{2}{*}{$\chi^{2}$ of $\beta_{\text {High }}=\beta_{\text {Low }}(p-$ value $)$} & $0.06(0.80)$ & $0.00(0.95)$ & $0.03(0.87)$ \\
\hline & \multicolumn{3}{|c|}{ Panel V: Individual High Intensity Components } \\
\hline \multirow[t]{2}{*}{ Written Records \& Reporting } & 0.002 & 0.002 & 0.002 \\
\hline & $(0.006)$ & $(0.006)$ & $(0.006)$ \\
\hline \multirow[t]{2}{*}{ Investigations } & 0.003 & 0.005 & 0.007 \\
\hline & $(0.006)$ & $(0.006)$ & $(0.006)$ \\
\hline \multirow[t]{2}{*}{ Consequences } & -0.003 & -0.004 & -0.005 \\
\hline & $(0.006)$ & $(0.005)$ & $(0.005)$ \\
\hline \multirow[t]{2}{*}{ Training \& Transparency } & 0.005 & 0.006 & 0.006 \\
\hline & $(0.008)$ & $(0.008)$ & $(0.008)$ \\
\hline \multirow[t]{2}{*}{ Legal Definitions } & -0.006 & -0.007 & -0.008 \\
\hline & $(0.006)$ & $(0.005)$ & $(0.005)$ \\
\hline
\end{tabular}


Table 8: Difference-in-Difference Estimates of Relationship between ABLs and Teen School Shootings and Teen Arrest Rates

\begin{tabular}{|c|c|c|c|c|}
\hline & \multicolumn{2}{|c|}{ Teen School Shootings } & \multicolumn{2}{|c|}{ Teen Arrest Rates } \\
\hline & $\begin{array}{c}\text { Shooting } \\
\text { Involving } \\
\text { Deaths } \\
\text { (1) }\end{array}$ & $\begin{array}{c}\text { Shooting } \\
\text { Involving } \\
\text { Homicide } \\
\text { (2) }\end{array}$ & $\begin{array}{c}\text { Property } \\
\text { Crime } \\
(3) \\
\end{array}$ & $\begin{array}{c}\text { Violent } \\
\text { Crime } \\
(4) \\
\end{array}$ \\
\hline & \multicolumn{4}{|c|}{ Panel I: Any ABL } \\
\hline \multirow[t]{2}{*}{$\mathrm{ABL}$} & $\begin{array}{l}-0.031 \\
(0.059)\end{array}$ & $\begin{array}{l}-0.063 \\
(0.038)\end{array}$ & $\begin{array}{l}-0.113 \\
(0.075)\end{array}$ & $\begin{array}{c}-0.142 * * \\
(0.070)\end{array}$ \\
\hline & \multicolumn{4}{|c|}{ Panel II: Model Policy } \\
\hline ABL with Model Policy & $\begin{array}{l}-0.037 \\
(0.072)\end{array}$ & $\begin{array}{l}-0.064 \\
(0.046)\end{array}$ & $\begin{array}{l}-0.139 \\
(0.095)\end{array}$ & $\begin{array}{l}-0.136 \\
(0.089)\end{array}$ \\
\hline ABL without Model Policy & $\begin{array}{l}-0.007 \\
(0.111)\end{array}$ & $\begin{array}{l}-0.056 \\
(0.120)\end{array}$ & $\begin{array}{l}-0.002 \\
(0.064)\end{array}$ & $\begin{array}{l}-0.166 \\
(0.126)\end{array}$ \\
\hline \multirow[t]{2}{*}{$\chi^{2}$ of $\beta_{\mathrm{MP}}=\beta_{\mathrm{No} \mathrm{MP}}(p-$ value $)$} & $0.04(0.84)$ & $0.00(0.95)$ & $1.09(0.30)$ & $0.03(0.86)$ \\
\hline & \multicolumn{4}{|c|}{ Panel III: Intensity Rating } \\
\hline High Intensity ABL & $\begin{array}{l}-0.195^{*} \\
(0.109)\end{array}$ & $\begin{array}{c}-0.235^{* *} \\
(0.099)\end{array}$ & $\begin{array}{l}-0.098 \\
(0.093)\end{array}$ & $\begin{array}{l}-0.115 \\
(0.120)\end{array}$ \\
\hline Moderate Intensity ABL & $\begin{array}{c}0.013 \\
(0.083)\end{array}$ & $\begin{array}{c}0.010 \\
(0.068)\end{array}$ & $\begin{array}{l}-0.180 \\
(0.147)\end{array}$ & $\begin{array}{l}-0.205 \\
(0.127)\end{array}$ \\
\hline Low Intensity ABL & $\begin{array}{c}0.026 \\
(0.078)\end{array}$ & $\begin{array}{l}-0.074 \\
(0.118)\end{array}$ & $\begin{array}{l}0.035 \\
(0.059)\end{array}$ & $\begin{array}{l}-0.018 \\
(0.123)\end{array}$ \\
\hline $\begin{array}{l}\chi^{2} \text { of } \beta_{\text {High }}=\beta_{\text {Moderate }}(p-\text {-value }) \\
\chi^{2} \text { of } \beta_{\text {High }}=\beta_{\text {Low }}(p \text {-value })\end{array}$ & $\begin{array}{l}2.42(0.13) \\
2.94(0.09)\end{array}$ & $\begin{array}{l}3.07(0.09) \\
1.09(0.30)\end{array}$ & $\begin{array}{l}0.18(0.67) \\
1.72(0.20)\end{array}$ & $\begin{array}{l}0.22(0.64) \\
0.35(0.56)\end{array}$ \\
\hline & \multicolumn{4}{|c|}{ Panel IV: School District Policy Intensity Rating } \\
\hline High Intensity District Policy & $\begin{array}{l}-0.074 \\
(0.125)\end{array}$ & $\begin{array}{l}-0.100 \\
(0.124)\end{array}$ & $\begin{array}{l}-0.463 \\
(0.281)\end{array}$ & $\begin{array}{l}-0.451 * \\
(0.240)\end{array}$ \\
\hline Moderate Intensity District Policy & $\begin{array}{l}-0.021 \\
(0.088)\end{array}$ & $\begin{array}{l}-0.045 \\
(0.063)\end{array}$ & $\begin{array}{l}-0.012 \\
(0.051)\end{array}$ & $\begin{array}{l}-0.039 \\
(0.067)\end{array}$ \\
\hline Low Intensity District Policy & $\begin{array}{l}-0.002 \\
(0.093)\end{array}$ & $\begin{array}{l}-0.060 \\
(0.115)\end{array}$ & $\begin{array}{c}0.039 \\
(0.061)\end{array}$ & $\begin{array}{l}-0.048 \\
(0.111)\end{array}$ \\
\hline \multirow[t]{2}{*}{$\chi^{2}$ of $\beta_{\text {High }}=\beta_{\text {Low }}(p-$ value $)$} & $\begin{array}{l}0.11(0.74) \\
0.21(0.65)\end{array}$ & $\begin{array}{l}0.12(0.73) \\
0.05(0.83)\end{array}$ & $\begin{array}{l}2.43(0.13) \\
2.80(0.10)\end{array}$ & $\begin{array}{l}2.69(0.11) \\
2.16(0.15)\end{array}$ \\
\hline & \multicolumn{4}{|c|}{ Panel V: Individual High Intensity Components } \\
\hline Written Records \& Reporting & $\begin{array}{l}-0.147 \\
(0.122)\end{array}$ & $\begin{array}{l}-0.168 \\
(0.112)\end{array}$ & $\begin{array}{l}-0.040 \\
(0.209)\end{array}$ & $\begin{array}{l}-0.059 \\
(0.200)\end{array}$ \\
\hline Investigations & $\begin{array}{c}0.017 \\
(0.125)\end{array}$ & $\begin{array}{c}0.077 \\
(0.120)\end{array}$ & $\begin{array}{c}-0.079 \\
(0.276)\end{array}$ & $\begin{array}{c}0.002 \\
(0.260)\end{array}$ \\
\hline Consequences & $\begin{array}{l}-0.013 \\
(0.102)\end{array}$ & $\begin{array}{c}0.058 \\
(0.067)\end{array}$ & $\begin{array}{c}0.151 \\
(0.129)\end{array}$ & $\begin{array}{c}0.113 \\
(0.138)\end{array}$ \\
\hline Training \& Transparency & $\begin{array}{c}0.035 \\
(0.112)\end{array}$ & $\begin{array}{l}-0.020 \\
(0.086)\end{array}$ & $\begin{array}{l}-0.027 \\
(0.153)\end{array}$ & $\begin{array}{l}-0.108 \\
(0.153)\end{array}$ \\
\hline Legal Definitions & $\begin{array}{l}-0.070 \\
(0.099)\end{array}$ & $\begin{array}{c}-0.198^{* *} \\
(0.085)\end{array}$ & $\begin{array}{c}-0.329 * * \\
(0.159)\end{array}$ & $\begin{array}{l}-0.301 * \\
(0.163)\end{array}$ \\
\hline
\end{tabular}




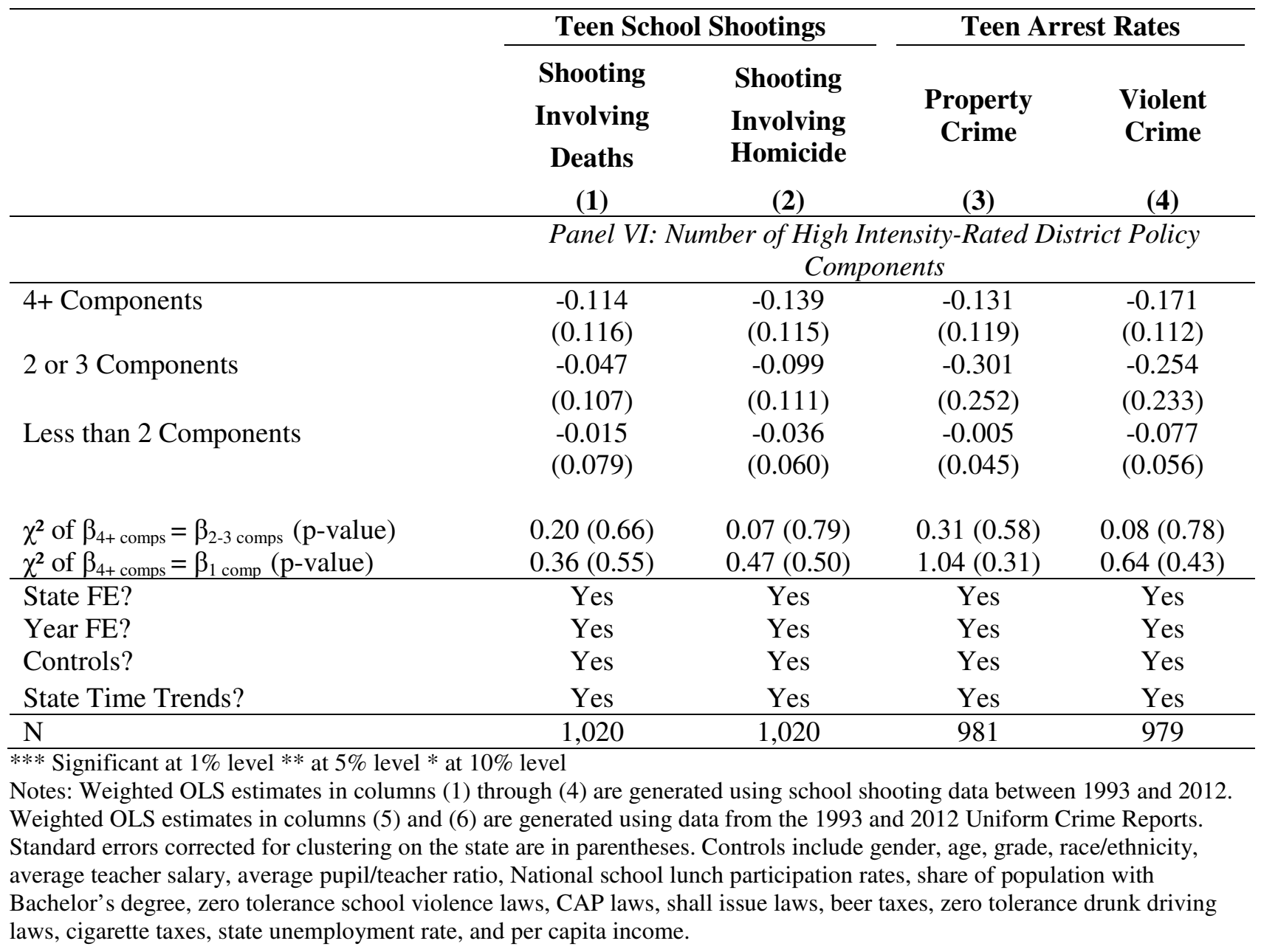


Table 9: Falsification Tests on Safety

\begin{tabular}{|c|c|c|c|c|c|c|c|}
\hline & \multicolumn{6}{|c|}{ Older Young Adults } & \multirow{3}{*}{$\begin{array}{c}\text { Teen } \\
\text { Safety } \\
\begin{array}{c}\text { No Helmet } \\
\text { Use }\end{array}\end{array}$} \\
\hline & \multicolumn{2}{|c|}{ College Shootings } & \multicolumn{2}{|c|}{ Arrest Rates } & \multicolumn{2}{|c|}{ Neighborhood Safety } & \\
\hline & $\begin{array}{c}\text { Shooting } \\
\text { Involving } \\
\text { Deaths }\end{array}$ & $\begin{array}{l}\text { Shooting } \\
\text { Involving } \\
\text { Homicide }\end{array}$ & $\begin{array}{c}\text { Property } \\
\text { Crime }\end{array}$ & $\begin{array}{l}\text { Violent } \\
\text { Crime }\end{array}$ & Fear & Shotgun & \\
\hline & (1) & (2) & (3) & (4) & (5) & (6) & $(7)$ \\
\hline & & \multicolumn{6}{|c|}{ Panel I: Any ABL } \\
\hline $\mathrm{ABL}$ & $\begin{array}{c}0.004 \\
(0.054)\end{array}$ & $\begin{array}{c}0.061 \\
(0.037)\end{array}$ & $\begin{array}{c}-0.100 \\
(0.094)\end{array}$ & $\begin{array}{c}-0.139 \\
(0.123)\end{array}$ & $\begin{array}{c}-0.177 \\
(0.130)\end{array}$ & $\begin{array}{c}0.083 \\
(0.103)\end{array}$ & $\begin{array}{c}0.002 \\
(0.004)\end{array}$ \\
\hline & & \multicolumn{6}{|c|}{ Panel II: Model Policy } \\
\hline ABL with Model Policy & $\begin{array}{c}0.029 \\
(0.052)\end{array}$ & $\begin{array}{c}0.072 \\
(0.045)\end{array}$ & $\begin{array}{c}-0.107 \\
(0.120)\end{array}$ & $\begin{array}{c}-0.131 \\
(0.157)\end{array}$ & $\begin{array}{c}-0.101 \\
(0.146)\end{array}$ & $\begin{array}{c}0.004 \\
(0.123)\end{array}$ & $\begin{array}{c}0.003 \\
(0.004)\end{array}$ \\
\hline ABL without Model Policy & $\begin{array}{c}-0.097 \\
(0.093)\end{array}$ & $\begin{array}{c}0.015 \\
(0.064)\end{array}$ & $\begin{array}{c}-0.070 \\
(0.078)\end{array}$ & $\begin{array}{c}-0.173 \\
(0.106)\end{array}$ & $\begin{array}{c}-0.301 \\
(0.195)\end{array}$ & $\begin{array}{c}0.188 \\
(0.146)\end{array}$ & $\begin{array}{c}0.000 \\
(0.007)\end{array}$ \\
\hline$\chi^{2}$ of $\beta_{\mathrm{MP}}=\beta_{\mathrm{No} \mathrm{MP}}(\mathrm{p}$-value $)$ & $1.81(0.19)$ & $0.49(0.49)$ & $0.05(082)$ & $0.04(0.84)$ & $0.71(0.40)$ & $1.02(0.32)$ & $0.10(0.75)$ \\
\hline & & \multicolumn{6}{|c|}{ Panel III: Intensity Rating } \\
\hline High Intensity ABL & $\begin{array}{c}-0.027 \\
(0.059)\end{array}$ & $\begin{array}{c}0.001 \\
(0.049)\end{array}$ & $\begin{array}{c}-0.001 \\
(0.079)\end{array}$ & $\begin{array}{c}-0.004 \\
(0.105)\end{array}$ & $\begin{array}{c}-0.126 \\
(0.172)\end{array}$ & $\begin{array}{c}-0.114 \\
(0.156)\end{array}$ & $\begin{array}{c}0.003 \\
(0.005)\end{array}$ \\
\hline Moderate Intensity ABL & $\begin{array}{c}0.046 \\
(0.066)\end{array}$ & $\begin{array}{c}0.094 \\
(0.062)\end{array}$ & $\begin{array}{c}-0.178 \\
(0.182)\end{array}$ & $\begin{array}{c}-0.242 \\
(0.241)\end{array}$ & $\begin{array}{c}-0.174 \\
(0.219)\end{array}$ & $\begin{array}{l}0.235^{*} \\
(0.130)\end{array}$ & $\begin{array}{c}0.004 \\
(0.005)\end{array}$ \\
\hline Low Intensity ABL & $\begin{array}{c}-0.074 \\
(0.101)\end{array}$ & $\begin{array}{l}0.037 * \\
(0.021)\end{array}$ & $\begin{array}{c}-0.001 \\
(0.070)\end{array}$ & $\begin{array}{l}-0.011 \\
(0.109)\end{array}$ & $\begin{array}{l}-0.237 \\
(0.313)\end{array}$ & $\begin{array}{l}-0.022 \\
(0.152)\end{array}$ & $\begin{array}{l}-0.007 \\
(0.009)\end{array}$ \\
\hline $\begin{array}{l}\chi^{2} \text { of } \beta_{\text {High }}=\beta_{\text {Moderate }}(p \text {-value }) \\
\chi^{2} \text { of } \beta_{\text {High }}=\beta_{\text {I }}(p \text {-value })\end{array}$ & $\begin{array}{l}0.66(0.42) \\
0.24(0.63)\end{array}$ & $\begin{array}{l}1.32(0.26) \\
0.47(0.50)\end{array}$ & $\begin{array}{l}0.64(0.43) \\
0.00(1.00)\end{array}$ & $\begin{array}{l}0.65(0.43) \\
0.00(0.96)\end{array}$ & $\begin{array}{l}0.03(0.87) \\
0.08(0.78)\end{array}$ & $\begin{array}{c}3.15(0.008) \\
0.18(0.67)\end{array}$ & $\begin{array}{l}0.01(0.90) \\
1.10(0.29)\end{array}$ \\
\hline & & \multicolumn{6}{|c|}{ Panel IV: School District Policy Intensity Rating } \\
\hline High Intensity District Policy & $\begin{array}{c}0.064 \\
(0.110)\end{array}$ & $\begin{array}{c}0.095 \\
(0.103)\end{array}$ & $\begin{array}{c}-0.415 \\
(0.335)\end{array}$ & $\begin{array}{c}-0.592 \\
(0.463)\end{array}$ & $\begin{array}{c}0.101 \\
(0.208)\end{array}$ & $\begin{array}{c}0.054 \\
(0.134)\end{array}$ & $\begin{array}{c}0.001 \\
(0.005)\end{array}$ \\
\hline Moderate Intensity District Policy & $\begin{array}{c}0.006 \\
(0.051)\end{array}$ & $\begin{array}{c}0.058 \\
(0.047)\end{array}$ & $\begin{array}{c}0.024 \\
(0.079)\end{array}$ & $\begin{array}{c}0.031 \\
(0.081)\end{array}$ & $\begin{array}{c}-0.202 \\
(0.190)\end{array}$ & $\begin{array}{c}0.130 \\
(0.170)\end{array}$ & $\begin{array}{c}0.006 \\
(0.006)\end{array}$ \\
\hline Low Intensity District Policy & -0.080 & 0.024 & -0.035 & -0.028 & -0.309 & -0.015 & -0.003 \\
\hline
\end{tabular}




\begin{tabular}{|c|c|c|c|c|c|c|c|}
\hline & \multicolumn{6}{|c|}{ Older Young Adults } & \multirow{3}{*}{$\begin{array}{c}\text { Teen } \\
\text { Safety } \\
\begin{array}{c}\text { No Helmet } \\
\text { Use }\end{array} \\
\end{array}$} \\
\hline & \multicolumn{2}{|c|}{ College Shootings } & \multicolumn{2}{|c|}{ Arrest Rates } & \multicolumn{2}{|c|}{ Neighborhood Safety } & \\
\hline & $\begin{array}{c}\text { Shooting } \\
\text { Involving } \\
\text { Deaths }\end{array}$ & $\begin{array}{l}\text { Shooting } \\
\text { Involving } \\
\text { Homicide }\end{array}$ & $\begin{array}{c}\text { Property } \\
\text { Crime }\end{array}$ & $\begin{array}{l}\text { Violent } \\
\text { Crime }\end{array}$ & Fear & Shotgun & \\
\hline & (1) & (2) & (3) & $(4)$ & (5) & (6) & $(7)$ \\
\hline & $(0.097)$ & $(0.021)$ & $(0.061)$ & $(0.097)$ & $(0.302)$ & $(0.137)$ & $(0.007)$ \\
\hline$\chi^{2}$ of $\beta_{\text {High }}=\beta_{\text {Moderate }}(p$-value $)$ & $0.21(0.65)$ & $0.10(0.76)$ & $1.59(0.21)$ & $1.73(0.19)$ & $1.12(0.30)$ & $0.12(0.74)$ & $0.67(0.41)$ \\
\hline$\chi^{2}$ of $\beta_{\text {High }}=\beta_{\text {Low }}(p$-value $)$ & $1.17(0.28)$ & $0.43(0.51)$ & $1.15(0.29)$ & $1.32(0.26)$ & $1.11(0.30)$ & $0.12(0.74)$ & $0.32(0.57)$ \\
\hline & & \multicolumn{6}{|c|}{ Panel V: Individual High Intensity Components } \\
\hline Written Records \& Reporting & $\begin{array}{c}0.105 \\
(0.071)\end{array}$ & $\begin{array}{c}0.100 \\
(0.077)\end{array}$ & $\begin{array}{l}-0.067 \\
(0.226)\end{array}$ & $\begin{array}{l}-0.055 \\
(0.295)\end{array}$ & $\begin{array}{l}-0.306 \\
(0.249)\end{array}$ & $\begin{array}{c}0.241 \\
(0.171)\end{array}$ & $\begin{array}{c}-0.001 \\
(0.008)\end{array}$ \\
\hline Investigations & $\begin{array}{c}0.036 \\
(0.094)\end{array}$ & $\begin{array}{l}-0.017 \\
(0.091)\end{array}$ & $\begin{array}{l}-0.019 \\
(0.335)\end{array}$ & $\begin{array}{l}-0.141 \\
(0.455)\end{array}$ & $\begin{array}{l}-0.106 \\
(0.378)\end{array}$ & $\begin{array}{c}-0.044 \\
(0.336)\end{array}$ & $\begin{array}{c}0.004 \\
(0.007)\end{array}$ \\
\hline Consequences & $\begin{array}{l}-0.118 \\
(0.064)\end{array}$ & $\begin{array}{l}-0.072 \\
(0.049)\end{array}$ & $\begin{array}{c}0.252 \\
(0.163)\end{array}$ & $\begin{array}{c}0.252 \\
(0.225)\end{array}$ & $\begin{array}{c}0.139 \\
(0.173)\end{array}$ & $\begin{array}{c}0.009 \\
(0.155)\end{array}$ & $\begin{array}{c}0.004 \\
(0.005)\end{array}$ \\
\hline Training \& Transparency & $\begin{array}{c}0.030 \\
(0.076)\end{array}$ & $\begin{array}{l}-0.012 \\
(0.079)\end{array}$ & $\begin{array}{c}0.006 \\
(0.170)\end{array}$ & $\begin{array}{c}0.079 \\
(0.227)\end{array}$ & $\begin{array}{c}0.473 \\
(0.333)\end{array}$ & $\begin{array}{l}-0.211 \\
(0.259)\end{array}$ & $\begin{array}{l}-0.007 \\
(0.007)\end{array}$ \\
\hline Legal Definitions & $\begin{array}{c}0.113 \\
(0.083) \\
\end{array}$ & $\begin{array}{c}0.174 * * \\
(0.081)\end{array}$ & $\begin{array}{c}-0.369 * \\
(0.197)\end{array}$ & $\begin{array}{l}-0.380 \\
(0.259)\end{array}$ & $\begin{array}{l}-0.218 \\
(0.417)\end{array}$ & $\begin{array}{c}0.117 \\
(0.270)\end{array}$ & $\begin{array}{l}-0.001 \\
(0.007)\end{array}$ \\
\hline & & \multicolumn{6}{|c|}{ Panel VI: Number of High Intensity-Rated District Policy Components } \\
\hline 4+ Components & $\begin{array}{c}0.112 \\
(0.080)\end{array}$ & $\begin{array}{c}0.086 \\
(0.078)\end{array}$ & $\begin{array}{c}-0.031 \\
(0.105)\end{array}$ & $\begin{array}{l}-0.039 \\
(0.101)\end{array}$ & $\begin{array}{c}-0.002 \\
(0.489)\end{array}$ & $\begin{array}{l}-0.030 \\
(0.375)\end{array}$ & $\begin{array}{c}0.007 * \\
(0.004)\end{array}$ \\
\hline 2 or 3 Components & $\begin{array}{c}0.054 \\
(0.093)\end{array}$ & $\begin{array}{c}0.097 \\
(0.088)\end{array}$ & $\begin{array}{l}-0.233 \\
(0.307)\end{array}$ & $\begin{array}{l}-0.337 \\
(0.418)\end{array}$ & $\begin{array}{l}-0.276 \\
(0.175)\end{array}$ & $\begin{array}{c}0.094 \\
(0.214)\end{array}$ & $\begin{array}{l}-0.006 \\
(0.006)\end{array}$ \\
\hline Less than 2 Components & $\begin{array}{l}-0.032 \\
(0.064)\end{array}$ & $\begin{array}{c}0.039 \\
(0.043)\end{array}$ & $\begin{array}{l}-0.034 \\
(0.056)\end{array}$ & $\begin{array}{l}-0.040 \\
(0.057)\end{array}$ & $\begin{array}{l}-0.120 \\
(0.209)\end{array}$ & $\begin{array}{c}0.082 \\
(0.122)\end{array}$ & $\begin{array}{c}0.005 \\
(0.005)\end{array}$ \\
\hline$\chi^{2}$ of $\beta_{4+\text { comps }}=\beta_{2-3 \text { comps }}(p-$ value $)$ & $0.24(0.63)$ & $0.01(0.93)$ & $0.32(0.57)$ & $0.40(0.53)$ & $0.27(0.61)$ & $0.13(0.72)$ & $5.07(0.02)$ \\
\hline$\chi^{2}$ of $\beta_{4+\text { comps }}=\beta_{1 \text { comp }}(\mathrm{p}$-value $)$ & $1.99(0.16)$ & $0.30(0.59)$ & $0.00(0.98)$ & $0.00(1.00)$ & $0.05(0.82)$ & $0.06(0.80)$ & $0.16(0.69)$ \\
\hline State FE? & Yes & Yes & Yes & Yes & Yes & Yes & Yes \\
\hline Year FE? & Yes & Yes & Yes & Yes & Yes & Yes & Yes \\
\hline Controls? & Yes & Yes & Yes & Yes & Yes & Yes & Yes \\
\hline
\end{tabular}




\begin{tabular}{|c|c|c|c|c|c|c|c|}
\hline & \multicolumn{6}{|c|}{ Older Young Adults } & \multirow{3}{*}{$\begin{array}{c}\text { Teen } \\
\text { Safety } \\
\begin{array}{c}\text { No Helmet } \\
\text { Use }\end{array}\end{array}$} \\
\hline & \multicolumn{2}{|c|}{ College Shootings } & \multicolumn{2}{|c|}{ Arrest Rates } & \multicolumn{2}{|c|}{ Neighborhood Safety } & \\
\hline & $\begin{array}{c}\text { Shooting } \\
\text { Involving } \\
\text { Deaths }\end{array}$ & $\begin{array}{l}\text { Shooting } \\
\text { Involving } \\
\text { Homicide }\end{array}$ & $\begin{array}{c}\text { Property } \\
\text { Crime }\end{array}$ & $\begin{array}{l}\text { Violent } \\
\text { Crime }\end{array}$ & Fear & Shotgun & \\
\hline & (1) & (2) & (3) & (4) & (5) & (6) & (7) \\
\hline State Time Trends? & Yes & Yes & Yes & Yes & Yes & Yes & Yes \\
\hline $\mathrm{N}$ & 1,020 & 1,020 & 981 & 980 & $1,113^{\mathrm{b}}$ & $1,106^{\mathrm{b}}$ & 653,327 \\
\hline
\end{tabular}

Notes: Estimates in columns (1) and (2) are obtained using data from the 1993 to 2009 General Social Survey. Estimates in columns (3) through (6) and (7) through (8) are generated using school shooting data between 1993 and 2012. And estimates in columns (7) through (8) are generated using data from the 1993 to 2012 Uniform Crime Reports. Standard errors corrected for clustering on the state are in parentheses. Controls include gender, age, grade, race/ethnicity, average teacher salary, average pupil/teacher ratio, National school lunch participation rates, share of population with Bachelor's degree, zero tolerance school violence laws, CAP laws, shall issue laws, beer taxes, zero tolerance drunk driving laws, cigarette taxes, state unemployment rate, and per capita income. Estimates in columns (3) through (8) are weighted using the relevant population.

${ }^{\mathrm{b}}$ Individuals used to estimate the state-by-year regressions. 
Table 10: Difference-in-Difference-in-Difference Estimates of the Effect of ABLs on School Shootings and Arrest Rates

\begin{tabular}{|c|c|c|c|c|}
\hline & \multicolumn{2}{|c|}{ Teen School Shootings } & \multicolumn{2}{|c|}{ Teen Arrest Rates } \\
\hline & $\begin{array}{l}\text { Shooting } \\
\text { Involving } \\
\text { Deaths } \\
(1) \\
\end{array}$ & $\begin{array}{c}\text { Shooting } \\
\text { Involving } \\
\text { Homicide } \\
\text { (2) }\end{array}$ & $\begin{array}{c}\text { Property } \\
\text { Crime } \\
(3)\end{array}$ & $\begin{array}{c}\text { Violent } \\
\text { Crime } \\
(4) \\
\end{array}$ \\
\hline & \multicolumn{4}{|c|}{ Panel I: Any $A B L$} \\
\hline \multirow[t]{2}{*}{$\mathrm{ABL}$} & $\begin{array}{l}-0.036 \\
(0.089) \\
\end{array}$ & $\begin{array}{c}-0.124 * * \\
(0.049) \\
\end{array}$ & $\begin{array}{l}-0.017 \\
(0.031) \\
\end{array}$ & $\begin{array}{l}-0.008 \\
(0.065) \\
\end{array}$ \\
\hline & \multicolumn{4}{|c|}{ Panel II: Model Policy } \\
\hline ABL with Model Policy & $\begin{array}{l}-0.066 \\
(0.086)\end{array}$ & $\begin{array}{c}-0.136 * * \\
(0.053)\end{array}$ & $\begin{array}{c}-0.036 \\
(0.036)\end{array}$ & $\begin{array}{l}-0.010 \\
(0.080)\end{array}$ \\
\hline ABL without Model Policy & $\begin{array}{c}0.089 \\
(0.156)\end{array}$ & $\begin{array}{l}-0.071 \\
(0.157)\end{array}$ & $\begin{array}{c}0.064 \\
(0.044)\end{array}$ & $\begin{array}{c}0.003 \\
(0.040)\end{array}$ \\
\hline \multirow[t]{2}{*}{$\chi^{2}$ of $\beta_{\mathrm{MP}}=\beta_{\mathrm{No} M P}(\mathrm{p}$-value $)$} & $0.92(0.34)$ & $0.15(0.70)$ & $3.34(0.07)$ & $0.02(0.88)$ \\
\hline & \multicolumn{4}{|c|}{ Panel III: Intensity Rating } \\
\hline High Intensity ABL & $\begin{array}{l}-0.169 \\
(0.121)\end{array}$ & $\begin{array}{c}-0.236 * * \\
(0.103)\end{array}$ & $\begin{array}{c}-0.098^{* *} \\
(0.048)\end{array}$ & $\begin{array}{l}-0.114 * * \\
(0.044)\end{array}$ \\
\hline Moderate Intensity ABL & $\begin{array}{l}-0.032 \\
(0.099)\end{array}$ & $\begin{array}{l}-0.084 \\
(0.093)\end{array}$ & $\begin{array}{l}-0.005 \\
(0.049)\end{array}$ & $\begin{array}{c}0.034 \\
(0.120)\end{array}$ \\
\hline Low Intensity ABL & $\begin{array}{c}0.100 \\
(0.132)\end{array}$ & $\begin{array}{l}-0.111 \\
(0.119)\end{array}$ & $\begin{array}{c}0.028 \\
(0.038)\end{array}$ & $\begin{array}{l}-0.013 \\
(0.043)\end{array}$ \\
\hline $\begin{array}{l}\chi^{2} \text { of } \beta_{\text {High }}=\beta_{\text {Moderate }}(p \text {-value }) \\
\chi^{2} \text { of } \beta_{\text {High }}=\beta_{\text {Low }}(p \text {-value })\end{array}$ & $\begin{array}{l}0.81(0.37) \\
3.00(0.09)\end{array}$ & $\begin{array}{l}0.81(0.37) \\
0.59(0.45)\end{array}$ & $\begin{array}{l}1.89(0.18) \\
4.52(0.04)\end{array}$ & $\begin{array}{l}1.16(0.29) \\
3.08(0.09)\end{array}$ \\
\hline & \multicolumn{4}{|c|}{ Panel IV: School District Policy Intensity Rating } \\
\hline High Intensity District Policy & $\begin{array}{l}-0.138 \\
(0.104)\end{array}$ & $\begin{array}{c}-0.194 * * \\
(0.075)\end{array}$ & $\begin{array}{l}-0.055 \\
(0.059)\end{array}$ & $\begin{array}{c}0.129 \\
(0.226)\end{array}$ \\
\hline Moderate Intensity District Policy & $\begin{array}{l}-0.027 \\
(0.107)\end{array}$ & $\begin{array}{l}-0.103 \\
(0.100)\end{array}$ & $\begin{array}{l}-0.036 \\
(0.045)\end{array}$ & $\begin{array}{l}-0.071^{*} \\
(0.040)\end{array}$ \\
\hline Low Intensity District Policy & $\begin{array}{c}0.078 \\
(0.140)\end{array}$ & $\begin{array}{l}-0.084 \\
(0.112)\end{array}$ & $\begin{array}{c}0.068 * * \\
(0.031)\end{array}$ & $\begin{array}{l}-0.024 \\
(0.045)\end{array}$ \\
\hline $\begin{array}{l}\chi^{2} \text { of } \beta_{\text {High }}=\beta_{\text {Moderate }}(p \text {-value }) \\
\chi^{2} \text { of } \beta_{\text {High }}=\beta_{\text {Low }}(p-\text {-value })\end{array}$ & $\begin{array}{l}0.61(0.44) \\
2.82(0.10)\end{array}$ & $\begin{array}{l}0.37(0.55) \\
0.58(0.45)\end{array}$ & $\begin{array}{l}0.07(0.79) \\
3.54(0.07)\end{array}$ & $\begin{array}{l}0.76(0.39) \\
0.42(0.52)\end{array}$ \\
\hline & \multicolumn{4}{|c|}{ Panel V: Individual High Intensity Components } \\
\hline Written Records \& Reporting & $\begin{array}{l}-0.252^{*} \\
(0.138)\end{array}$ & $\begin{array}{c}-0.268 * * \\
(0.132)\end{array}$ & $\begin{array}{c}0.053 \\
(0.087)\end{array}$ & $\begin{array}{l}-0.001 \\
(0.124)\end{array}$ \\
\hline Investigations & $\begin{array}{l}-0.020 \\
(0.136)\end{array}$ & $\begin{array}{c}0.093 \\
(0.105)\end{array}$ & $\begin{array}{c}0.143 \\
(0.107)\end{array}$ & $\begin{array}{c}0.142 \\
(0.207)\end{array}$ \\
\hline Consequences & $\begin{array}{c}0.105 \\
(0.131)\end{array}$ & $\begin{array}{l}0.130^{*} \\
(0.075)\end{array}$ & $\begin{array}{l}-0.105 \\
(0.098)\end{array}$ & $\begin{array}{l}-0.136 \\
(0.101)\end{array}$ \\
\hline Training \& Transparency & $\begin{array}{c}0.005 \\
(0.145)\end{array}$ & $\begin{array}{l}-0.008 \\
(0.114)\end{array}$ & $\begin{array}{c}0.030 \\
(0.092)\end{array}$ & $\begin{array}{c}-0.195^{*} \\
(0.116)\end{array}$ \\
\hline Legal Definitions & $\begin{array}{l}-0.183 \\
(0.149)\end{array}$ & $\begin{array}{c}-0.372 * * * \\
(0.119)\end{array}$ & $\begin{array}{l}-0.043 \\
(0.104)\end{array}$ & $\begin{array}{c}0.069 \\
(0.113)\end{array}$ \\
\hline
\end{tabular}




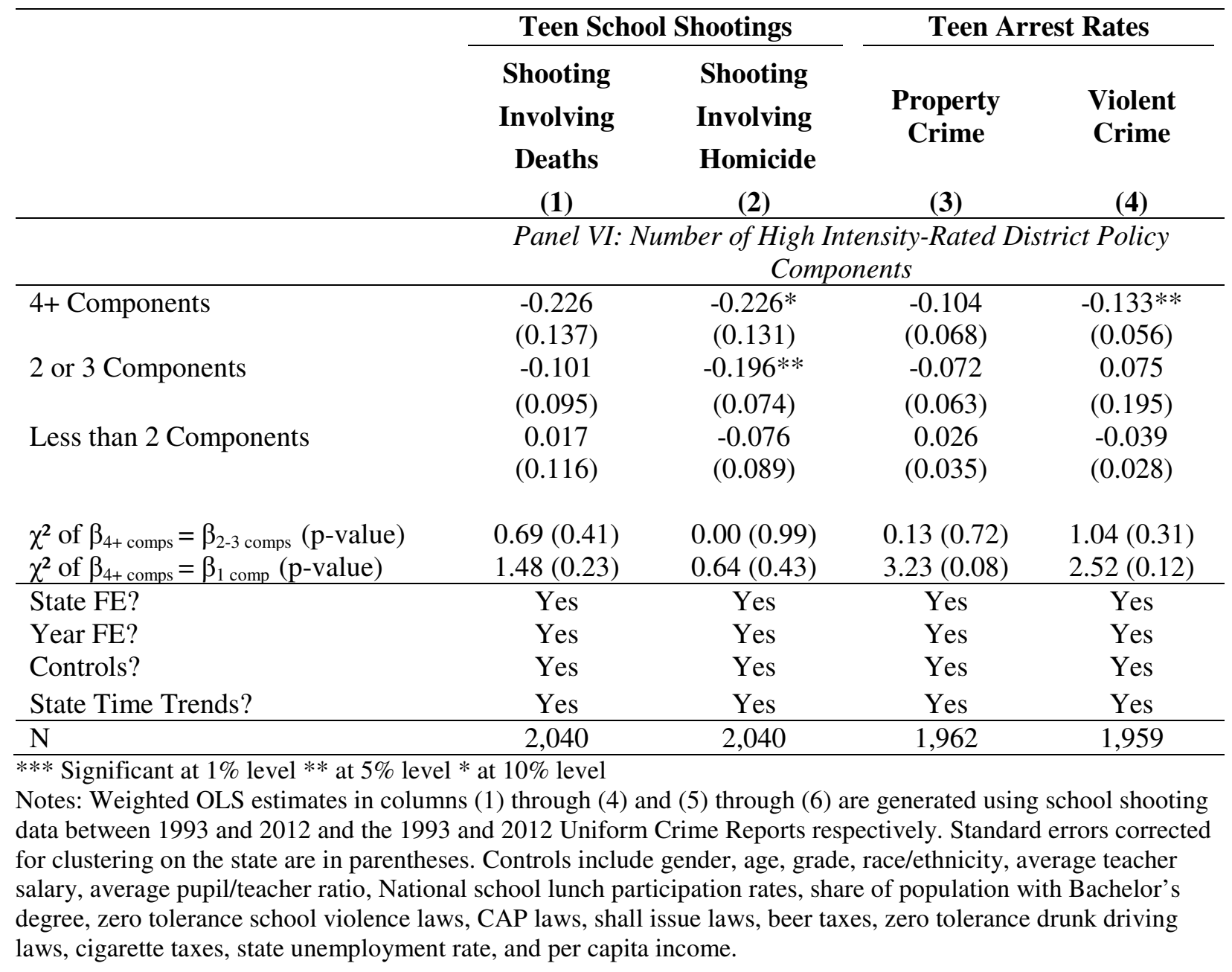


Appendix Table 1: Difference-in-Difference Estimates of Relationship between ABLs and School Safety Using Continuous Outcome Measures

\begin{tabular}{|c|c|c|c|c|}
\hline & $\begin{array}{l}\text { Unsafe } \\
\text { (1) }\end{array}$ & $\begin{array}{l}\text { Fight in } \\
\text { School } \\
\text { (2) }\end{array}$ & $\begin{array}{l}\text { All Fight } \\
\text { (3) }\end{array}$ & $\begin{array}{l}\text { Threat } \\
\text { (4) }\end{array}$ \\
\hline & \multicolumn{4}{|c|}{ Panel I: Any ABL } \\
\hline \multirow[t]{2}{*}{ ABL } & $\begin{array}{c}0.014 \\
(0.051)\end{array}$ & $\begin{array}{c}0.015 \\
(0.035)\end{array}$ & $\begin{array}{c}0.008 \\
(0.021)\end{array}$ & $\begin{array}{c}0.013 \\
(0.046)\end{array}$ \\
\hline & \multicolumn{4}{|c|}{ Panel II: Model Policy } \\
\hline ABL with Model Policy & $\begin{array}{c}0.020 \\
(0.053)\end{array}$ & $\begin{array}{c}0.022 \\
(0.041)\end{array}$ & $\begin{array}{c}0.011 \\
(0.022)\end{array}$ & $\begin{array}{c}0.029 \\
(0.051)\end{array}$ \\
\hline ABL without Model Policy & $\begin{array}{l}-0.026 \\
(0.118)\end{array}$ & $\begin{array}{l}-0.017 \\
(0.047)\end{array}$ & $\begin{array}{l}-0.011 \\
(0.054)\end{array}$ & $\begin{array}{l}-0.076 \\
(0.065)\end{array}$ \\
\hline \multirow[t]{2}{*}{$\chi^{2}$ of $\beta_{\mathrm{MP}}=\beta_{\mathrm{No} \mathrm{MP}}(\mathrm{p}$-value $)$} & $0.14(0.71)$ & $0.40(0.53)$ & $0.15(0.70)$ & $1.87(0.17)$ \\
\hline & \multicolumn{4}{|c|}{ Panel III: Intensity Rating } \\
\hline High Intensity ABL & $\begin{array}{l}-0.101 \\
(0.121)\end{array}$ & $\begin{array}{l}-0.101 \\
(0.068)\end{array}$ & $\begin{array}{l}-0.050 \\
(0.031)\end{array}$ & $\begin{array}{l}-0.038 \\
(0.110)\end{array}$ \\
\hline Moderate Intensity ABL & $\begin{array}{c}0.037 \\
(0.054)\end{array}$ & $\begin{array}{c}0.030 \\
(0.047)\end{array}$ & $\begin{array}{c}0.017 \\
(0.029)\end{array}$ & $\begin{array}{c}0.027 \\
(0.054)\end{array}$ \\
\hline Low Intensity ABL & $\begin{array}{c}0.124 \\
(0.093)\end{array}$ & $\begin{array}{l}0.152^{*} \\
(0.087)\end{array}$ & $\begin{array}{c}0.068 \\
(0.054)\end{array}$ & $\begin{array}{c}0.048 \\
(0.074)\end{array}$ \\
\hline \multirow{2}{*}{$\chi^{2}$ of $\beta_{\text {High }}=\beta_{\text {Low }}(p-$ value $)$} & $\begin{array}{l}1.09(0.30) \\
2.05(0.15)\end{array}$ & $\begin{array}{c}2.2(0.14) \\
4.55(0.03)\end{array}$ & $\begin{array}{l}2.42(0.12) \\
3.36(0.07)\end{array}$ & $\begin{array}{l}0.28(0.60) \\
0.37(0.54)\end{array}$ \\
\hline & \multicolumn{4}{|c|}{ Panel IV: School District Policy Intensity Rating } \\
\hline High Intensity District Policy & $\begin{array}{l}-0.045 \\
(0.095)\end{array}$ & $\begin{array}{l}-0.057 \\
(0.055)\end{array}$ & $\begin{array}{l}-0.012 \\
(0.030)\end{array}$ & $\begin{array}{l}-0.019 \\
(0.085)\end{array}$ \\
\hline Moderate Intensity District Policy & $\begin{array}{c}0.028 \\
(0.059)\end{array}$ & $\begin{array}{c}0.034 \\
(0.055)\end{array}$ & $\begin{array}{c}0.004 \\
(0.036)\end{array}$ & $\begin{array}{c}0.028 \\
(0.066)\end{array}$ \\
\hline Low Intensity District Policy & $\begin{array}{c}0.119 \\
(0.091)\end{array}$ & $\begin{array}{c}0.138 \\
(0.086)\end{array}$ & $\begin{array}{c}0.057 \\
(0.054)\end{array}$ & $\begin{array}{c}0.050 \\
(0.072)\end{array}$ \\
\hline \multirow[t]{2}{*}{$\chi^{2}$ of $\beta_{\text {High }}=\beta_{\text {Low }}(p-$ value $)$} & $\begin{array}{l}0.39(0.53) \\
1.55(0.21)\end{array}$ & $\begin{array}{l}1.19(0.27) \\
3.36(0.07)\end{array}$ & $\begin{array}{l}0.12(0.73) \\
1.21(0.27)\end{array}$ & $\begin{array}{l}0.18(0.67) \\
0.38(0.54)\end{array}$ \\
\hline & \multicolumn{4}{|c|}{ Panel V: Individual High Intensity Components } \\
\hline Written Records \& Reporting & $\begin{array}{c}-0.328 * * \\
(0.141)\end{array}$ & $\begin{array}{c}-0.275^{* * * *} \\
(0.076)\end{array}$ & $\begin{array}{l}-0.075 \\
(0.063)\end{array}$ & $\begin{array}{c}-0.339 * * * \\
(0.097)\end{array}$ \\
\hline Investigations & $\begin{array}{c}0.074 \\
(0.089)\end{array}$ & $\begin{array}{l}-0.040 \\
(0.065)\end{array}$ & $\begin{array}{c}0.018 \\
(0.042)\end{array}$ & $\begin{array}{l}-0.005 \\
(0.079)\end{array}$ \\
\hline Consequences & $\begin{array}{c}0.010 \\
(0.071)\end{array}$ & $\begin{array}{c}0.038 \\
(0.062)\end{array}$ & $\begin{array}{l}-0.000 \\
(0.040)\end{array}$ & $\begin{array}{l}-0.006 \\
(0.064)\end{array}$ \\
\hline Training \& Transparency & $\begin{array}{c}0.181 \\
(0.138)\end{array}$ & $\begin{array}{c}0.109 \\
(0.092)\end{array}$ & $\begin{array}{c}0.003 \\
(0.058)\end{array}$ & $\begin{array}{c}0.312 * * * \\
(0.103)\end{array}$ \\
\hline Legal Definitions & -0.060 & 0.010 & -0.016 & 0.063 \\
\hline
\end{tabular}




\begin{tabular}{|c|c|c|c|c|}
\hline & $\begin{array}{c}\text { Unsafe } \\
\text { (1) }\end{array}$ & $\begin{array}{c}\text { Fight in } \\
\text { School } \\
(2)\end{array}$ & $\begin{array}{c}\text { All Fight } \\
\text { (3) }\end{array}$ & $\begin{array}{c}\text { Threat } \\
\text { (4) }\end{array}$ \\
\hline & $(0.074)$ & $(0.053)$ & $(0.039)$ & $(0.079)$ \\
\hline & \multicolumn{4}{|c|}{$\begin{array}{c}\text { Panel VI: Number of High Intensity-Rated District } \\
\text { Policy Components }\end{array}$} \\
\hline 4+ Components & $\begin{array}{l}-0.222 \\
(0.138)\end{array}$ & $\begin{array}{l}-0.191 * * * \\
(0.073)\end{array}$ & $\begin{array}{l}-0.069 \\
(0.043)\end{array}$ & $\begin{array}{l}-0.171 \\
(0.123)\end{array}$ \\
\hline 2 or 3 Components & $\begin{array}{c}0.075 \\
(0.069)\end{array}$ & $\begin{array}{c}0.025 \\
(0.042)\end{array}$ & $\begin{array}{c}-0.005 \\
(0.030)\end{array}$ & $\begin{array}{c}0.092 \\
(0.065)\end{array}$ \\
\hline Less than 2 Components & $\begin{array}{c}0.054 \\
(0.057)\end{array}$ & $\begin{array}{c}0.082 \\
(0.054)\end{array}$ & $\begin{array}{c}0.046 \\
(0.034)\end{array}$ & $\begin{array}{c}0.015 \\
(0.052)\end{array}$ \\
\hline $\begin{array}{l}\chi^{2} \text { of } \beta_{4+\text { comps }}=\beta_{2-3 \text { comps }}(\mathrm{p} \text {-value }) \\
\chi^{2} \text { of } \beta_{4+\text { comps }}=\beta_{1 \text { comp }}(\mathrm{p} \text {-value })\end{array}$ & $\begin{array}{l}4.00(0.05) \\
3.49(0.06)\end{array}$ & $\begin{array}{l}6.67(0.01) \\
7.54(0.01)\end{array}$ & $\begin{array}{l}1.37(0.24) \\
4.03(0.04)\end{array}$ & $\begin{array}{l}4.15(0.04) \\
1.90(0.17)\end{array}$ \\
\hline State FE? & Yes & Yes & Yes & Yes \\
\hline Year FE? & Yes & Yes & Yes & Yes \\
\hline Controls? & Yes & Yes & Yes & Yes \\
\hline State Time Trends? & Yes & Yes & Yes & Yes \\
\hline $\mathrm{N}$ & $1,105,255$ & $1,054,461$ & $1,031,970$ & $1,070,208$ \\
\hline
\end{tabular}


Appendix Table 2: Difference-in-Difference Estimates of Relationship between ABLs and Bullying, Adding Controls for State-Specific Linear Time Trends

\begin{tabular}{|c|c|c|}
\hline & (1) & (2) \\
\hline & \multicolumn{2}{|c|}{ Panel I: Any $A B L$} \\
\hline \multirow[t]{2}{*}{ ABL } & $\begin{array}{l}-0.008 \\
(0.006)\end{array}$ & $\begin{array}{c}0.006 \\
(0.013)\end{array}$ \\
\hline & \multicolumn{2}{|c|}{ Panel II: Model Policy } \\
\hline ABL with Model Policy & $\begin{array}{l}-0.008 \\
(0.007)\end{array}$ & $\begin{array}{c}0.007 \\
(0.013)\end{array}$ \\
\hline ABL without Model Policy & $\begin{array}{l}-0.014 \\
(0.009)\end{array}$ & $\begin{array}{l}-0.032 \\
(0.025)\end{array}$ \\
\hline \multirow[t]{2}{*}{$\chi^{2}$ of $\beta_{\mathrm{MP}}=\beta_{\mathrm{No} M \mathrm{MP}}(\mathrm{p}-$ value $)$} & $0.35(0.56)$ & $2.20(0.14)$ \\
\hline & \multicolumn{2}{|c|}{ Panel III: Intensity Rating } \\
\hline High Intensity ABL & $\begin{array}{l}-0.019^{*} \\
(0.010)\end{array}$ & $\begin{array}{c}0.012 \\
(0.022)\end{array}$ \\
\hline Moderate Intensity ABL & $\begin{array}{l}-0.006 \\
(0.010)\end{array}$ & $\begin{array}{c}0.009 \\
(0.024)\end{array}$ \\
\hline Low Intensity ABL & $\begin{array}{l}-0.007 \\
(0.007)\end{array}$ & $\begin{array}{l}-0.009 \\
(0.011)\end{array}$ \\
\hline \multirow[t]{2}{*}{$\chi^{2}$ of $\beta_{\text {High }}=\beta_{\text {Low }}(\mathrm{p}$-value $)$} & $\begin{array}{l}0.70(0.40) \\
1.01(0.32) \\
\end{array}$ & $\begin{array}{l}0.01(0.93) \\
0.58(0.45)\end{array}$ \\
\hline & \multicolumn{2}{|c|}{ Panel IV: School District Policy Intensity Rating } \\
\hline High Intensity District Policy & $\begin{array}{l}-0.006 \\
(0.007)\end{array}$ & $\begin{array}{c}0.014 \\
(0.018)\end{array}$ \\
\hline Moderate Intensity District Policy & $\begin{array}{l}-0.015 \\
(0.018)\end{array}$ & $\begin{array}{l}-0.007 \\
(0.023)\end{array}$ \\
\hline Low Intensity District Policy & $\begin{array}{l}-0.007 \\
(0.007)\end{array}$ & $\begin{array}{l}-0.009 \\
(0.012)\end{array}$ \\
\hline \multirow[t]{2}{*}{$\chi^{2}$ of $\beta_{\text {High }}=\beta_{\text {Low }}(p-$ value $)$} & $\begin{array}{l}0.22(0.64) \\
0.01(0.92)\end{array}$ & $\begin{array}{l}0.66(0.42) \\
1.14(0.29)\end{array}$ \\
\hline & \multicolumn{2}{|c|}{ Panel V: Individual High Intensity Components } \\
\hline Written Records \& Reporting & $\begin{array}{c}0.013 \\
(0.017)\end{array}$ & $\begin{array}{c}0.043 \\
(0.056)\end{array}$ \\
\hline Investigations & $\begin{array}{l}-0.018 \\
(0.012)\end{array}$ & $\begin{array}{l}-0.032 \\
(0.039)\end{array}$ \\
\hline Consequences & $\begin{array}{l}-0.019^{*} \\
(0.012)\end{array}$ & $\begin{array}{c}0.038 \\
(0.031)\end{array}$ \\
\hline Training \& Transparency & $\begin{array}{c}0.014 \\
(0.021)\end{array}$ & $\begin{array}{c}0.001 \\
(0.041)\end{array}$ \\
\hline Legal Definitions & $\begin{array}{c}0.015 \\
(0.012)\end{array}$ & $\begin{array}{c}0.009 \\
(0.022)\end{array}$ \\
\hline
\end{tabular}


